\title{
Synthesis, Structures and Bonding of Metal-rich Metallaboranes Comprising Triply Bridging Borylene and Boride Moieties
}

Suman Gomosta, Sourav Kar, Alaka Nanda Pradhan, Subhash Bairagi, Venkatachalam Ramkumar, Sundargopal Ghosh ${ }^{*}, a$

aDepartment of Chemistry, Indian Institute of Technology Madras, Chennai 600036, India, Tel: +91 4422524230; Fax: 91-44-2257 4202,; Email: sghosh@iitm.ac.in 


\section{Table of Contents}

\section{Spectroscopic Details}

Figure S1. $\quad{ }^{1} \mathrm{H}$ NMR spectrum of $\mathbf{2}$ in $\mathrm{CDCl}_{3}$

Figure S2. $\quad{ }^{1} \mathrm{H}\left\{{ }^{11} \mathrm{~B}\right\}$ NMR spectrum of 2 in $\mathrm{CDCl}_{3}$

Figure S3. $\quad{ }^{11} \mathrm{~B}\left\{{ }^{1} \mathrm{H}\right\} \mathrm{NMR}$ spectrum of 2 in $\mathrm{CDCl}_{3}$

Figure S4. $\quad{ }^{11} \mathrm{~B}$ NMR spectrum of 2 in $\mathrm{CDCl}_{3}$

Figure S5. $\quad{ }^{13} \mathrm{C}\left\{{ }^{1} \mathrm{H}\right\}$ NMR spectrum of 2 in $\mathrm{CDCl}_{3}$

Figure S6. Mass spectral isotopic distribution for the fragment of 2.

Figure S7. IR spectrum of 2 in $\mathrm{CH}_{2} \mathrm{Cl}_{2}$

Figure S8. $\quad{ }^{1} \mathrm{H}$ NMR spectrum of $\mathbf{3}$ in $\mathrm{CDCl}_{3}$

Figure S9. $\quad{ }^{1} \mathrm{H}\left\{{ }^{11} \mathrm{~B}\right\}$ NMR spectrum of 3 in $\mathrm{CDCl}_{3}$

Figure $\mathrm{S} 10 . \quad{ }^{11} \mathrm{~B}\left\{{ }^{1} \mathrm{H}\right\} \mathrm{NMR}$ spectrum of $\mathbf{3}$ in $\mathrm{CDCl}_{3}$

Figure S11. $\quad{ }^{11} \mathrm{~B}$ NMR spectrum of $\mathbf{3}$ in $\mathrm{CDCl}_{3}$

Figure $\mathrm{S} 12$. $\quad{ }^{13} \mathrm{C}\left\{{ }^{1} \mathrm{H}\right\}$ NMR spectrum of $\mathbf{3}$ in $\mathrm{CDCl}_{3}$

Figure S13. HR-MS spectrum of 3 in $\mathrm{CH}_{2} \mathrm{Cl}_{2}-\mathrm{MeOH}$ mixture

Figure S14. IR spectrum of $\mathbf{3}$ in $\mathrm{CH}_{2} \mathrm{Cl}_{2}$

Figure S15. $\quad{ }^{1} \mathrm{H}$ NMR spectrum of 5 in $\mathrm{CDCl}_{3}$

Figure S16. $\quad{ }^{1} \mathrm{H}\left\{{ }^{11} \mathrm{~B}\right\}$ NMR spectrum of 5 in $\mathrm{CDCl}_{3}$

Figure S17. ${ }^{11} \mathrm{~B}\left\{{ }^{1} \mathrm{H}\right\}$ NMR spectrum of 5 in $\mathrm{CDCl}_{3}$

Figure S18. $\quad{ }^{11} \mathrm{~B}$ NMR spectrum of 5 in $\mathrm{CDCl}_{3}$

Figure S19. $\quad{ }^{13} \mathrm{C}\left\{{ }^{1} \mathrm{H}\right\}$ NMR spectrum of 5 in $\mathrm{CDCl}_{3}$

Figure S20. Mass spectral isotopic distribution for the fragment of 5

Figure S21. IR spectrum of 5 in $\mathrm{CH}_{2} \mathrm{Cl}_{2}$

Figure S22. $\quad{ }^{1} \mathrm{H}$ NMR spectrum of $\mathbf{6}$ in $\mathrm{CDCl}_{3}$

Figure $\mathrm{S} 23 . \quad{ }^{1} \mathrm{H}\left\{{ }^{11} \mathrm{~B}\right\}$ NMR spectrum of 6 in $\mathrm{CDCl}_{3}$

Figure S24. $\quad{ }^{11} \mathrm{~B}\left\{{ }^{1} \mathrm{H}\right\}$ NMR spectrum of 6 in $\mathrm{CDCl}_{3}$

Figure S25. $\quad{ }^{11} \mathrm{~B}$ NMR spectrum of 6 in $\mathrm{CDCl}_{3}$

Figure S26. $\quad{ }^{13} \mathrm{C}\left\{{ }^{1} \mathrm{H}\right\}$ NMR spectrum of 6 in $\mathrm{CDCl}_{3}$

Figure S27. Mass spectral isotopic distribution for the fragment of 6

Figure S28. IR spectrum of 6 in $\mathrm{CH}_{2} \mathrm{Cl}_{2}$

Figure S29. $\quad{ }^{1} \mathrm{H}$ NMR spectrum of $\mathbf{8}$ in $\mathrm{CDCl}_{3}$

Figure S30. $\quad{ }^{13} \mathrm{C}\left\{{ }^{1} \mathrm{H}\right\}$ NMR spectrum of 8 in $\mathrm{CDCl}_{3}$

Figure S31. Mass spectral isotopic distribution for the fragment of 8

Figure S32. IR spectrum of 8 in $\mathrm{CH}_{2} \mathrm{Cl}_{2}$ 
Figure S33. $\quad{ }^{11} \mathrm{~B}\left\{{ }^{1} \mathrm{H}\right\}$ NMR spectrum of $\mathbf{1 0}$ in $\mathrm{CDCl}_{3}$

II. Computational Details

III. Electronic Structure Analysis

Figure S34. Selected frontier molecular orbitals of 2

Figure S35. Selected frontier molecular orbitals of $\mathbf{3}$

Figure S36. NBO donor-acceptor interaction between B-H bonds and Co centres in 3

Figure S37. Selected frontier molecular orbitals of $\mathbf{5}$

Table S1. Calculated natural charges ( $\mathrm{qM}$ and $\mathrm{qB}$ ), natural valence population (Pop) and HOMO-LUMO gaps of 2, 3, 5, 6 and $\mathbf{1 0}$

Table S2. $\quad$ Experimetally observed and calculated ${ }^{11} \mathrm{~B}$ chemical shifts of compounds $\mathbf{2}$, $3, \mathbf{5}, \mathbf{6}$ and $\mathbf{1 0}$ 


\section{Spectroscopic Details}

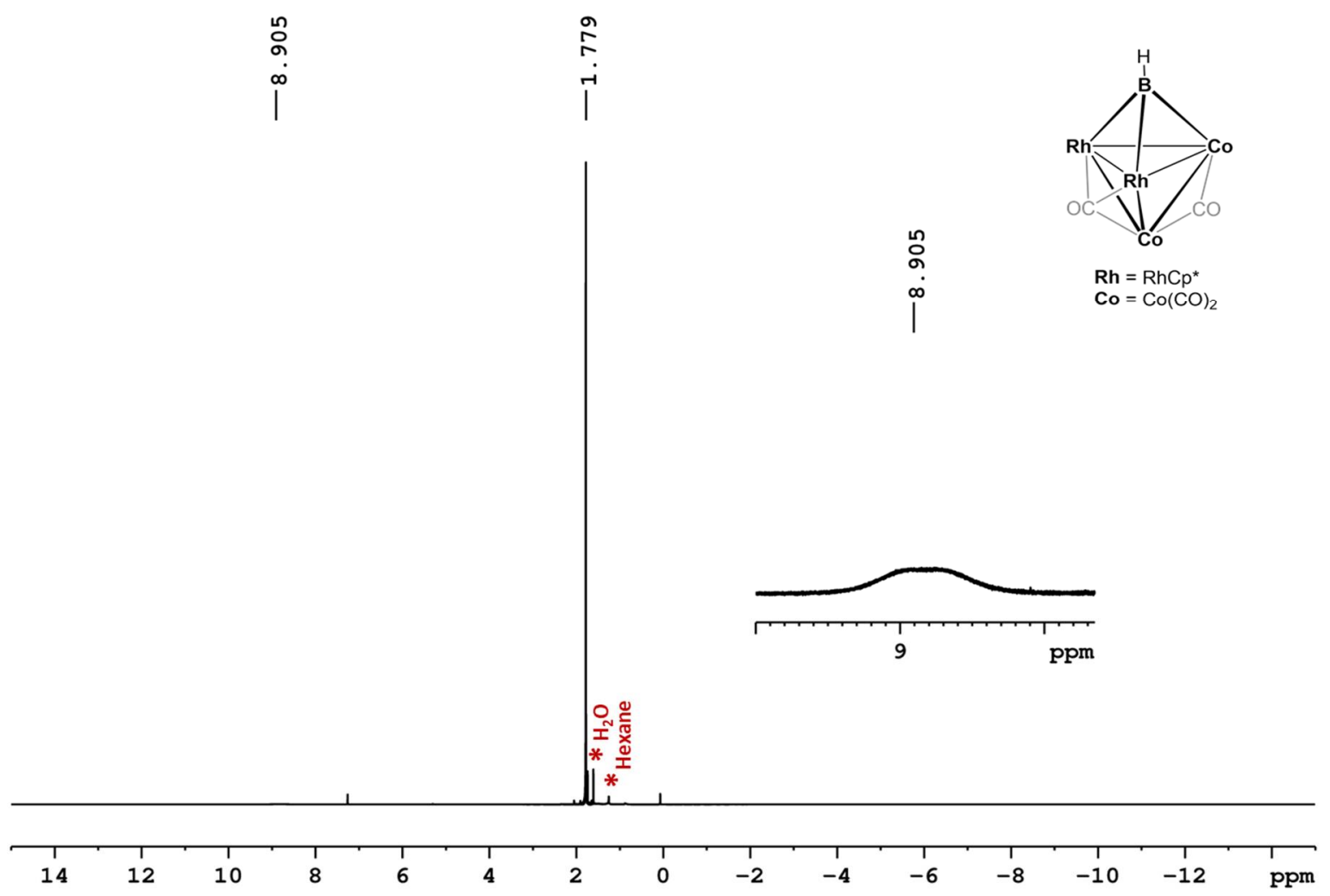

Figure S1. ${ }^{1} \mathrm{H}$ NMR spectrum of 2 in $\mathrm{CDCl}_{3}$

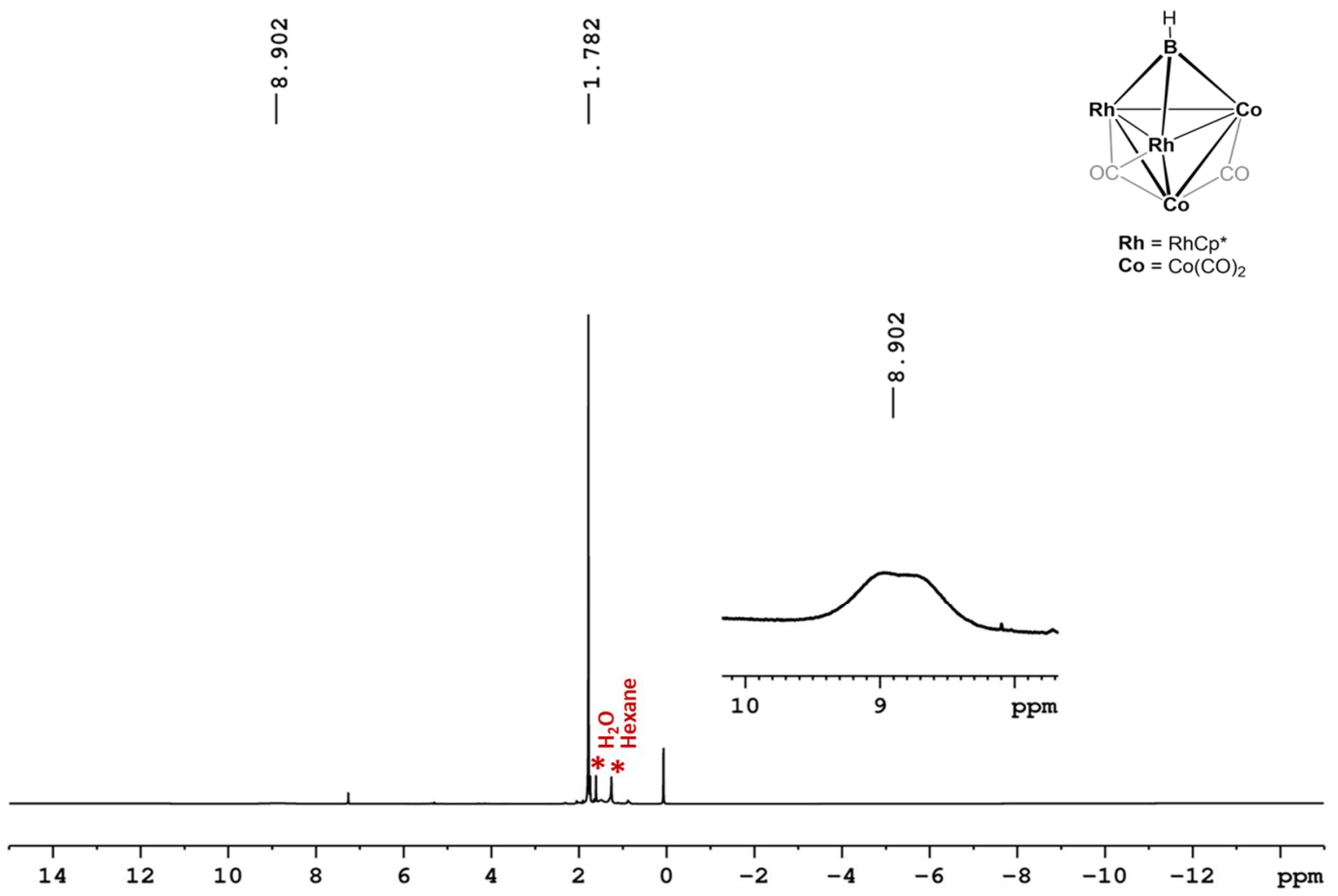

Figure S2. ${ }^{1} \mathrm{H}\left\{{ }^{11} \mathrm{~B}\right\} \mathrm{NMR}$ spectrum of $\mathbf{2}$ in $\mathrm{CDCl}_{3}$ 


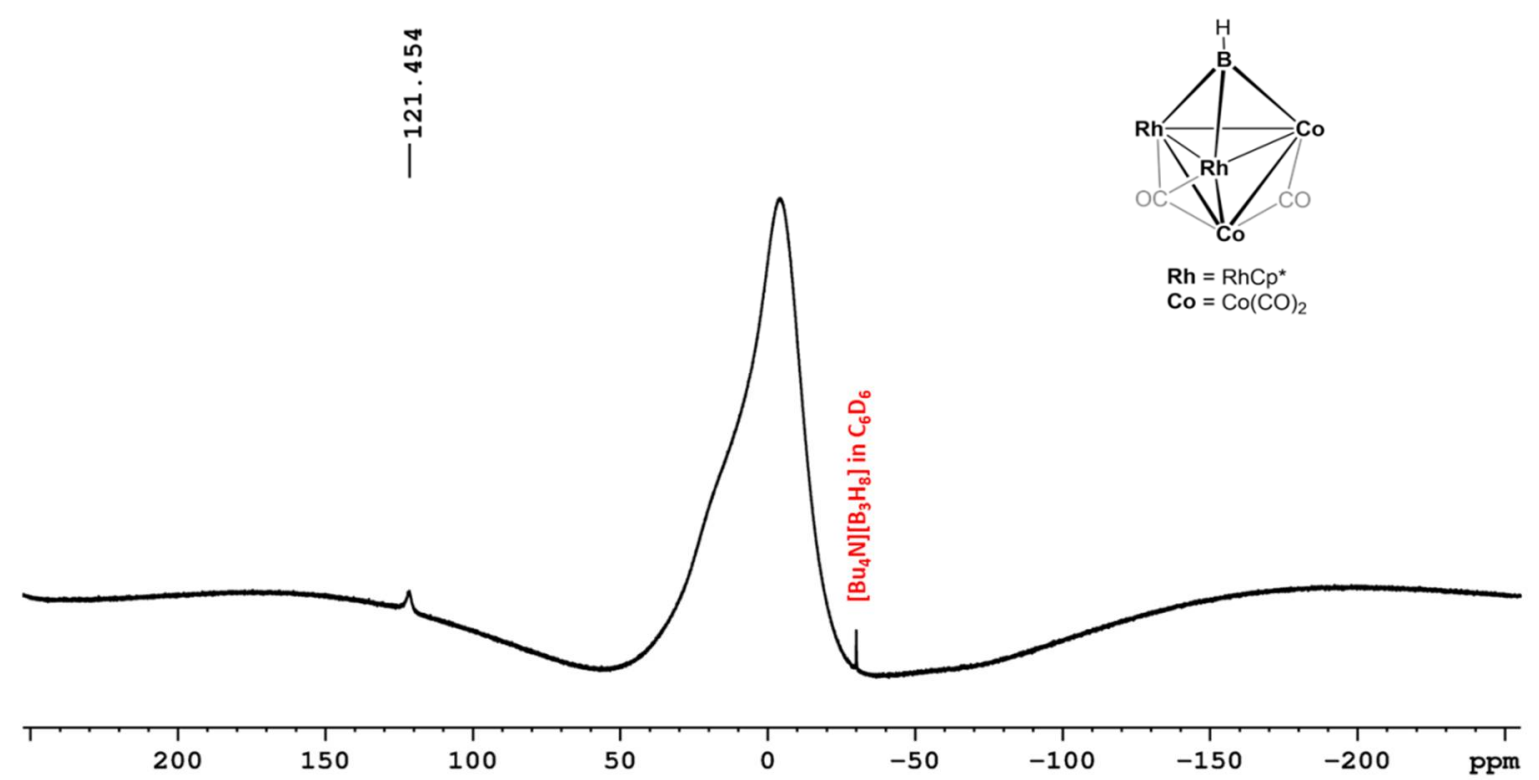

Figure S3. ${ }^{11} \mathrm{~B}\left\{{ }^{1} \mathrm{H}\right\}$ NMR spectrum of 2 in $\mathrm{CDCl}_{3}$

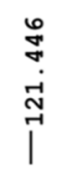

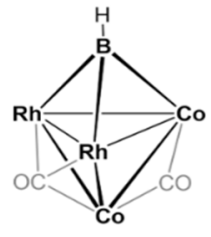

$\mathbf{R h}=\mathrm{RhCp}^{*}$ $\mathrm{Co}=\mathrm{Co}(\mathrm{CO})_{2}$

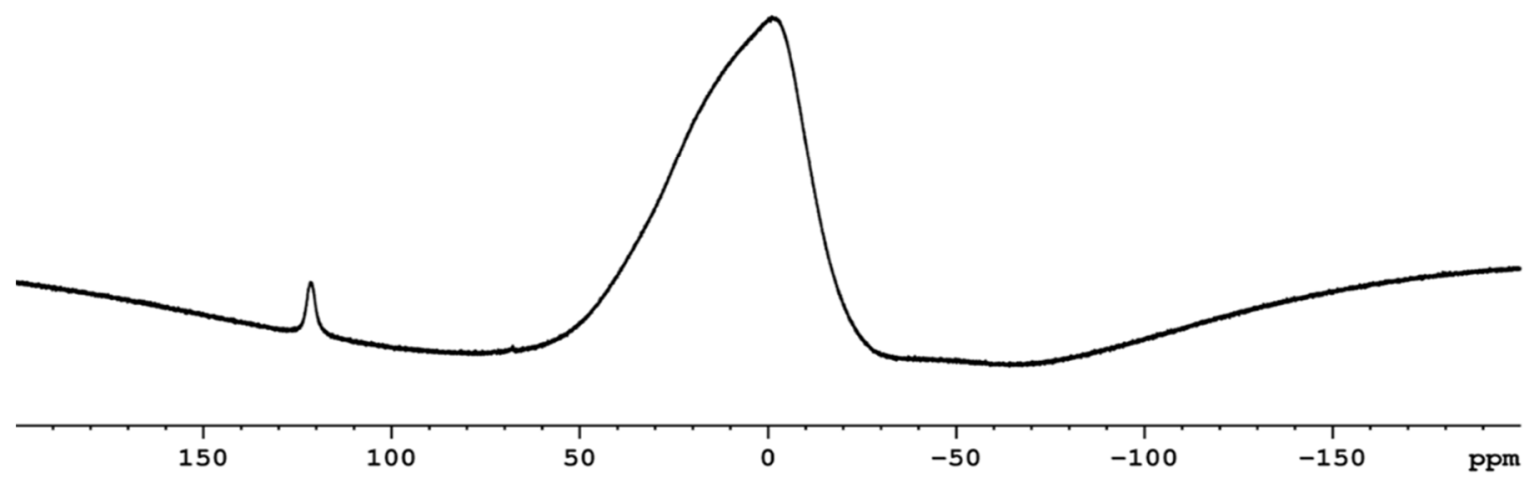

Figure S4. ${ }^{11} \mathrm{~B}$ NMR spectrum of 2 in $\mathrm{CDCl}_{3}$ 

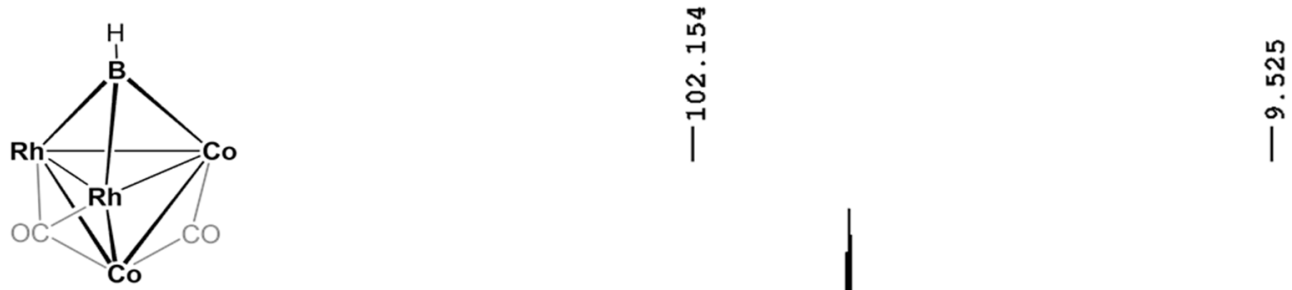

$\mathrm{Rh}=\mathrm{RhCp}^{*}$

$\mathrm{Co}=\mathrm{Co}(\mathrm{CO})_{2}$

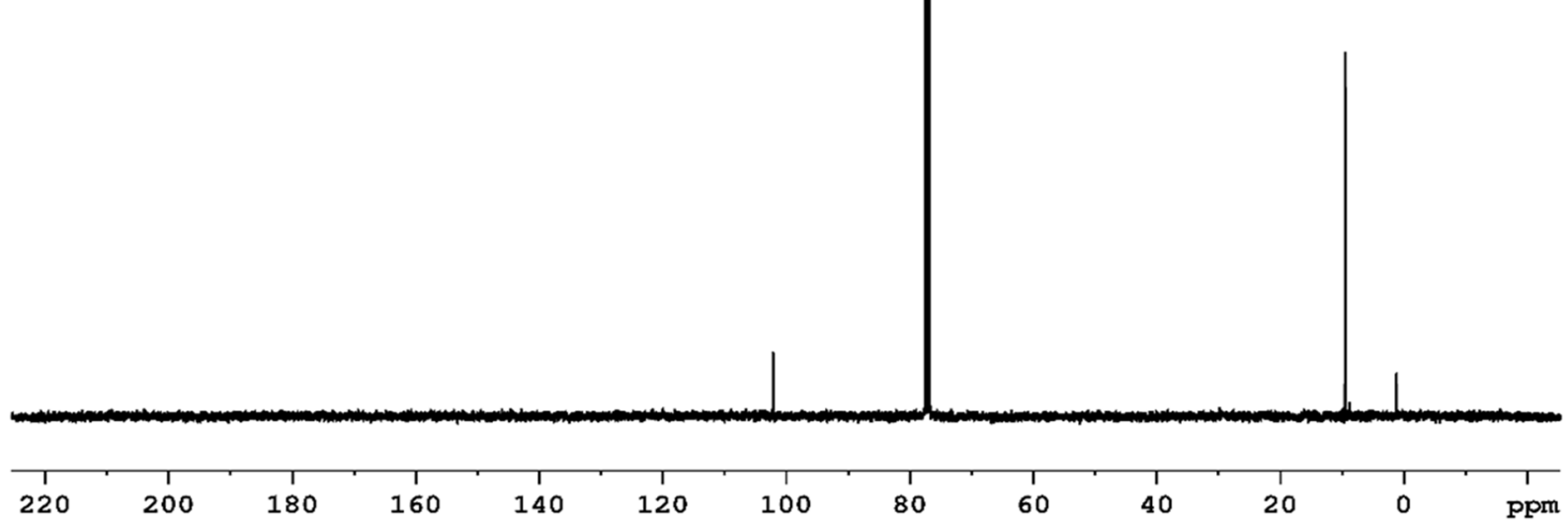

Figure S5. ${ }^{13} \mathrm{C}\left\{{ }^{1} \mathrm{H}\right\}$ NMR spectrum of 2 in $\mathrm{CDCl}_{3}$

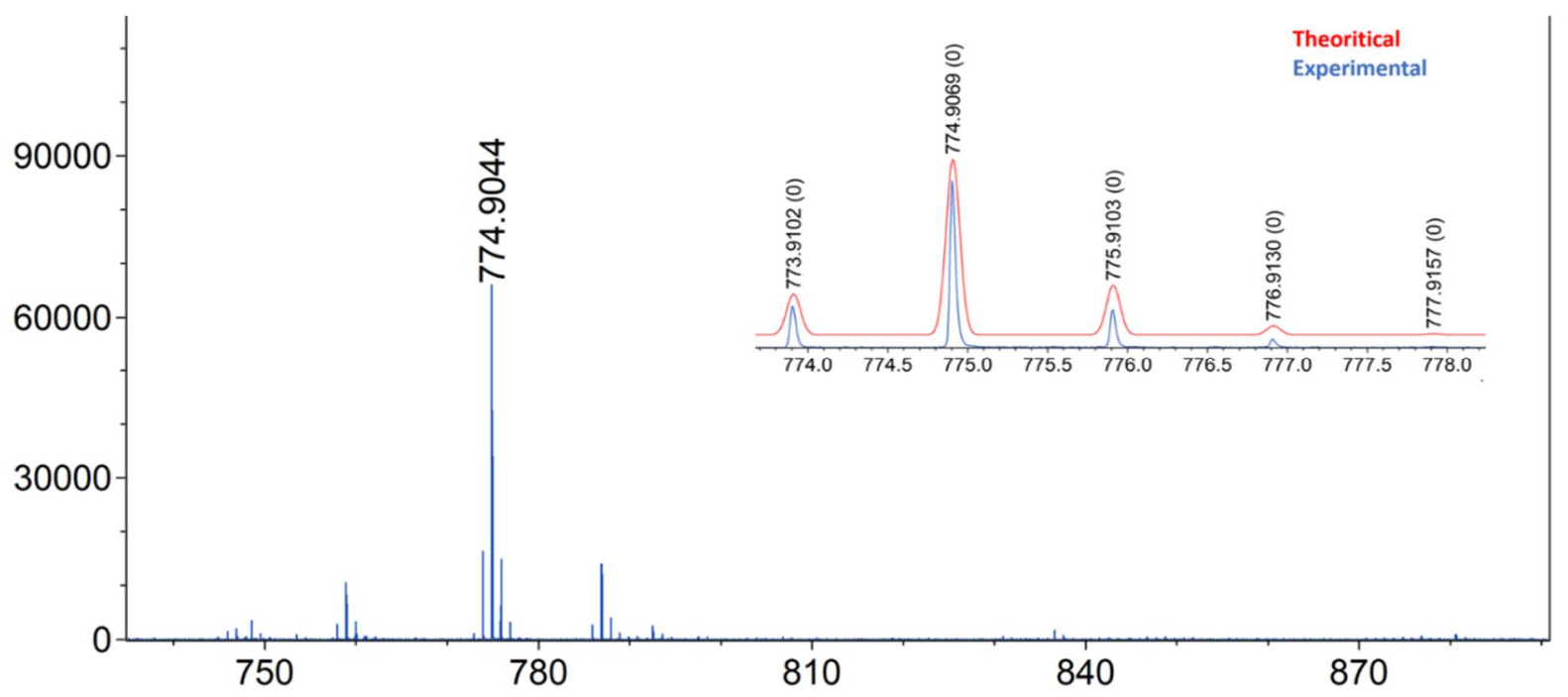

Figure S6. Calculated (red) and experimental (blue) mass spectral isotopic distribution for the fragment of 2 


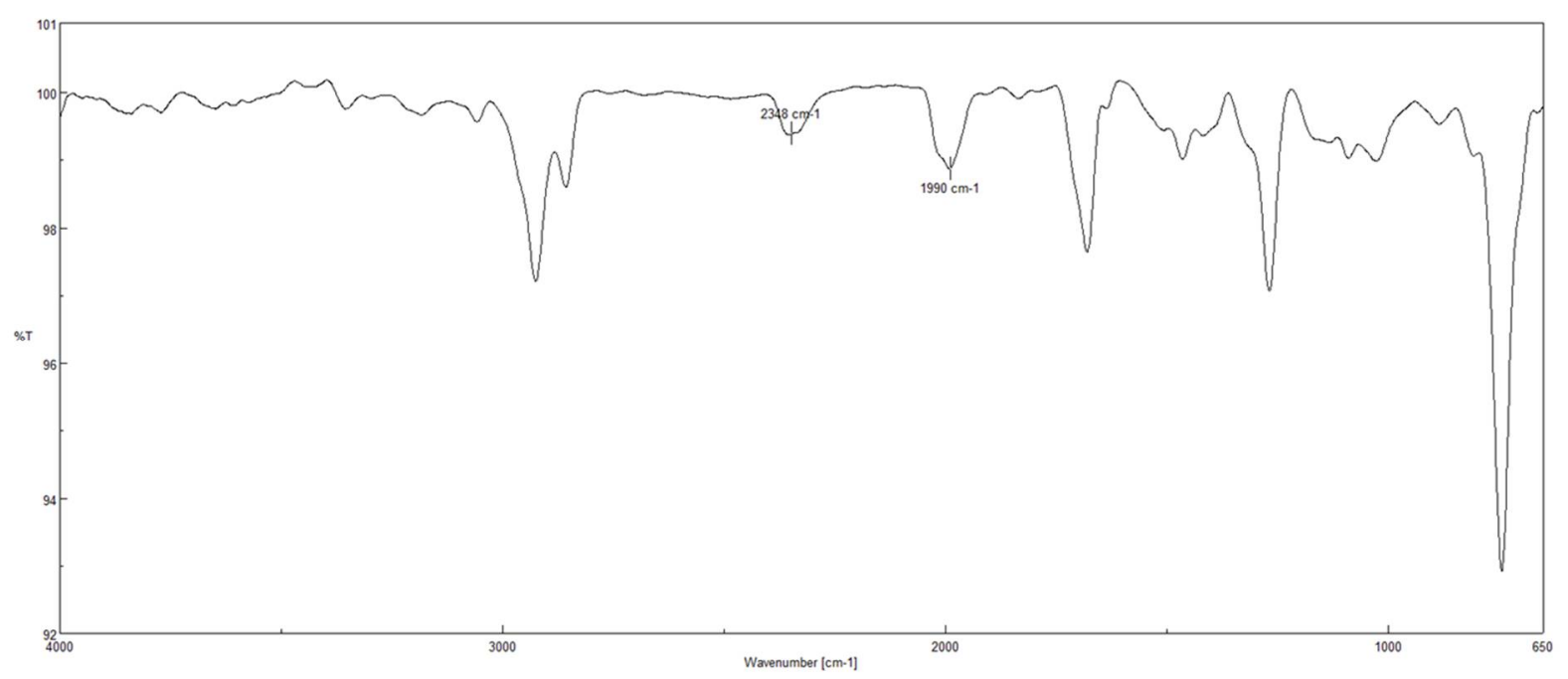

Figure S7. IR spectrum of 2 in $\mathrm{CH}_{2} \mathrm{Cl}_{2}$

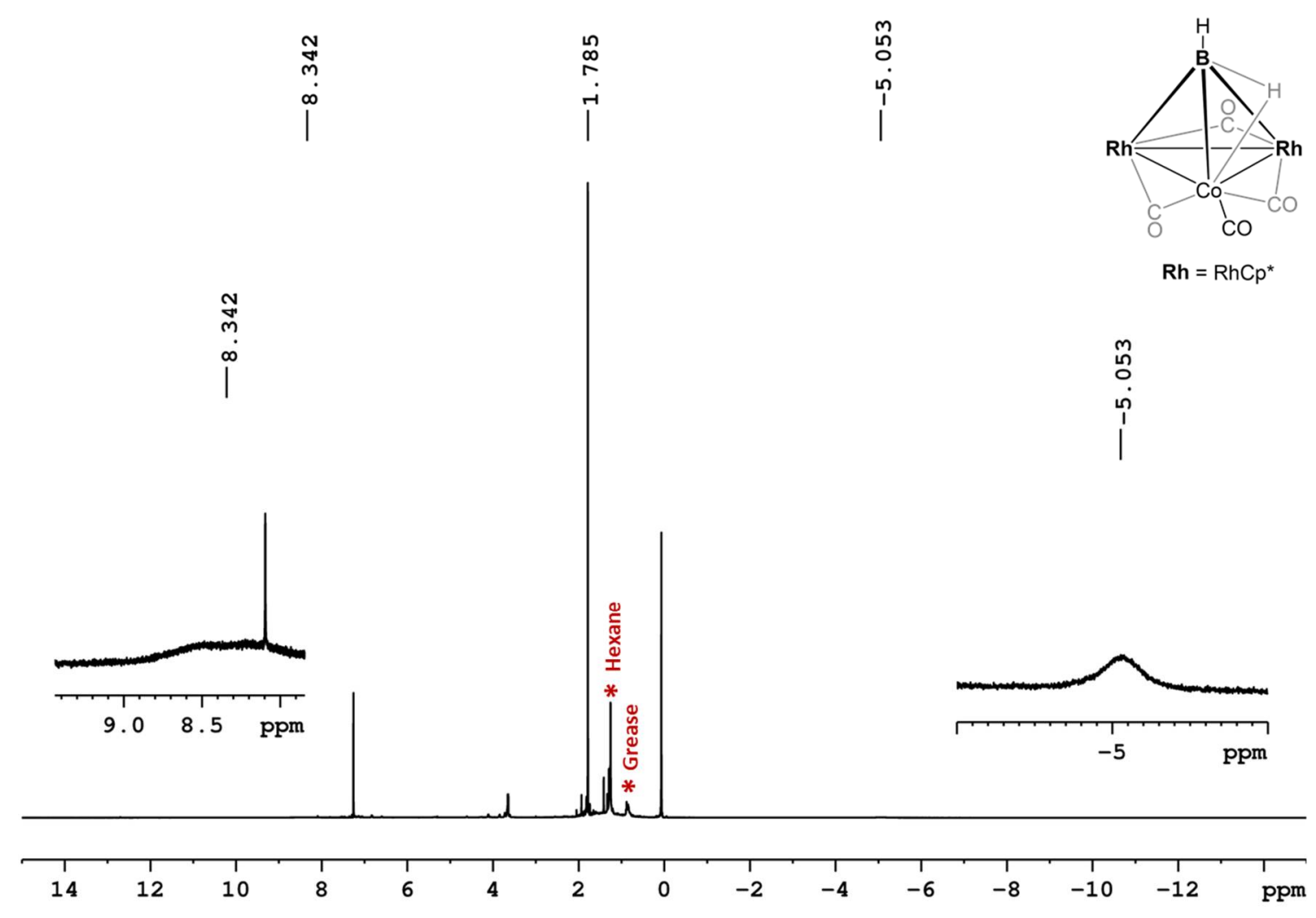

Figure S8. ${ }^{1} \mathrm{H}$ NMR spectrum of $\mathbf{3}$ in $\mathrm{CDCl}_{3}$ 


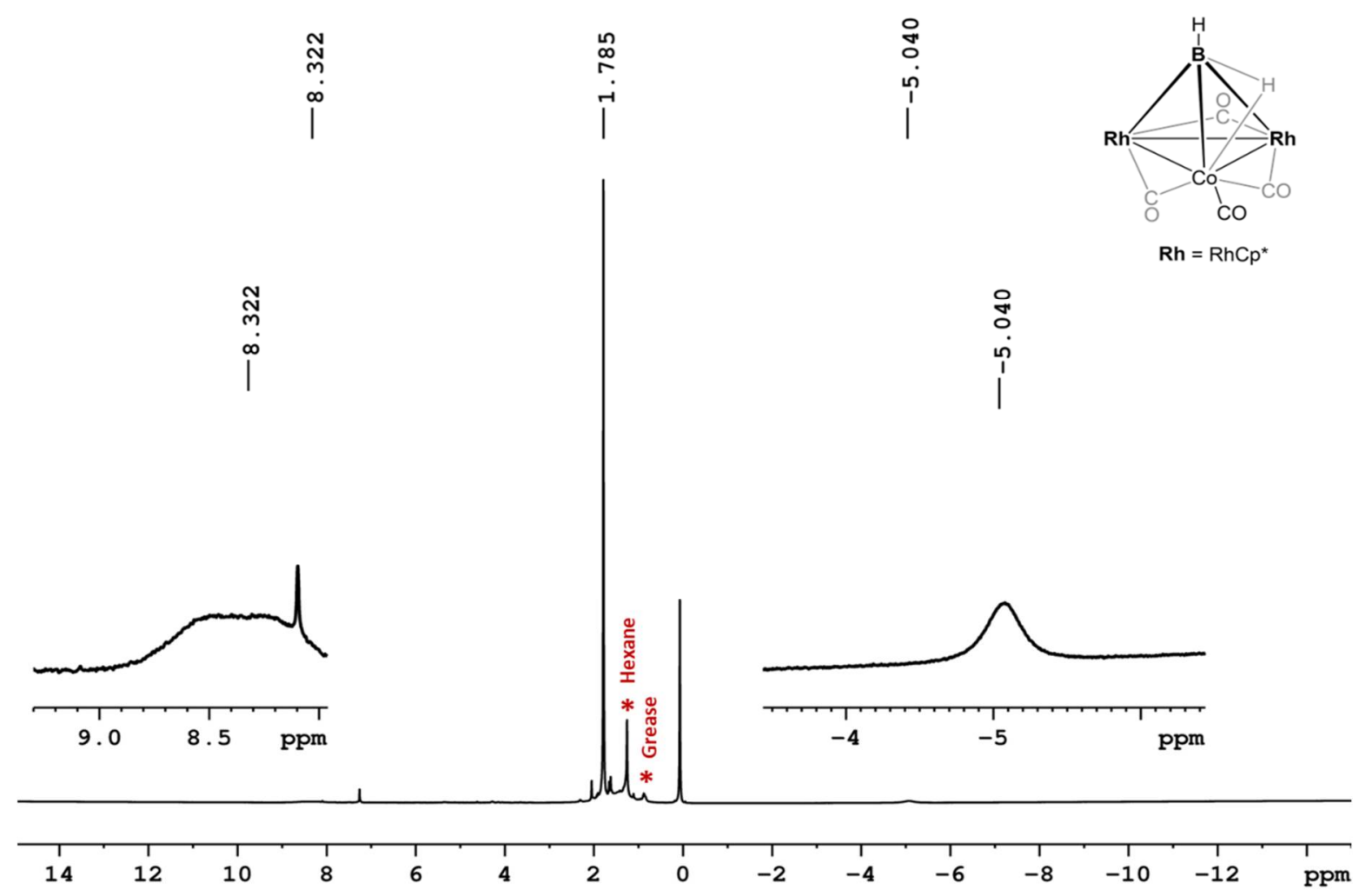

Figure S9. ${ }^{1} \mathrm{H}\left\{{ }^{11} \mathrm{~B}\right\}$ NMR spectrum of $\mathbf{3}$ in $\mathrm{CDCl}_{3}$

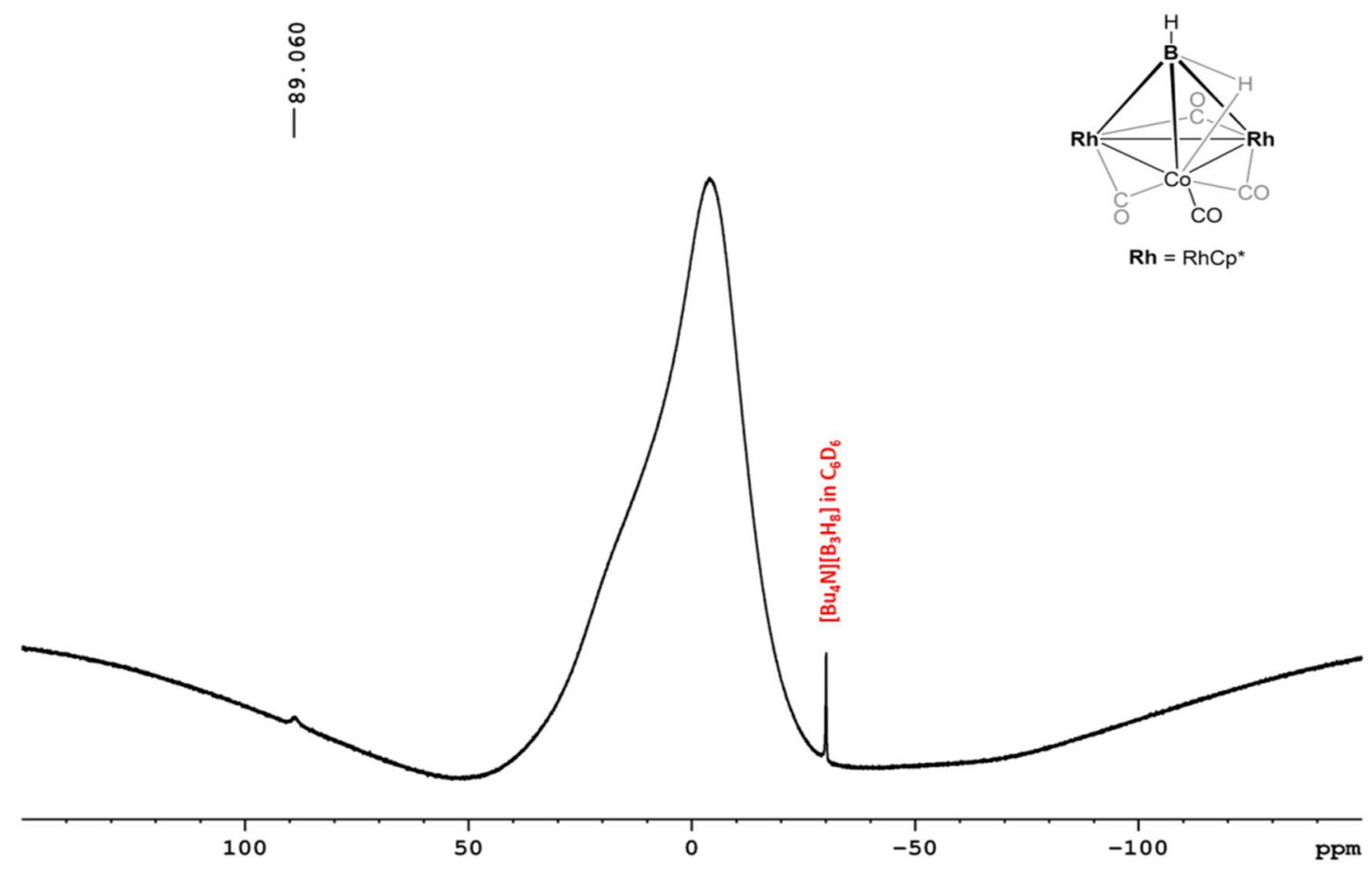

Figure S10. ${ }^{11} \mathrm{~B}\left\{{ }^{1} \mathrm{H}\right\}$ NMR spectrum of $\mathbf{3}$ in $\mathrm{CDCl}_{3}$ 


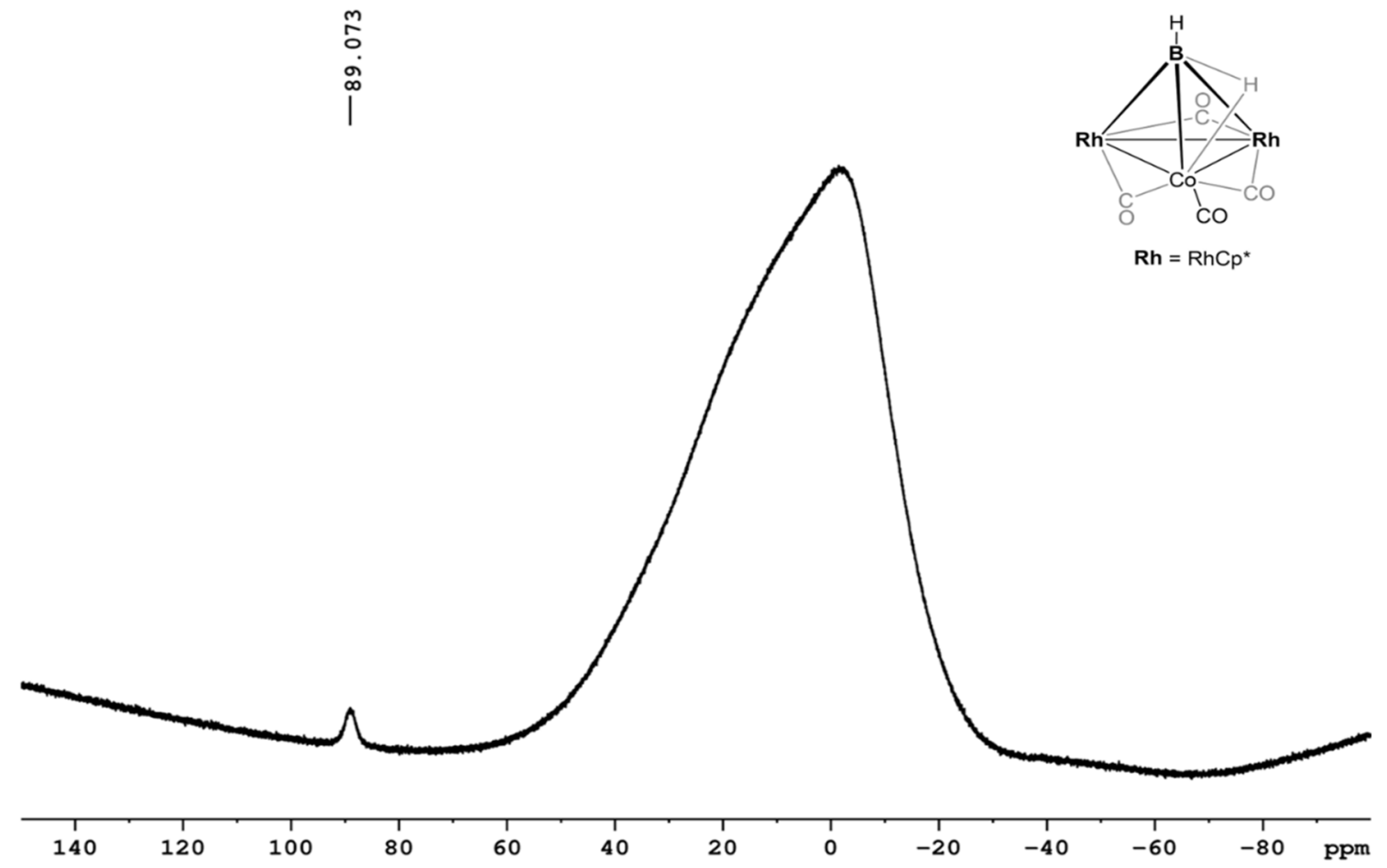

Figure S11. ${ }^{11} \mathrm{~B}$ NMR spectrum of 3 in $\mathrm{CDCl}_{3}$

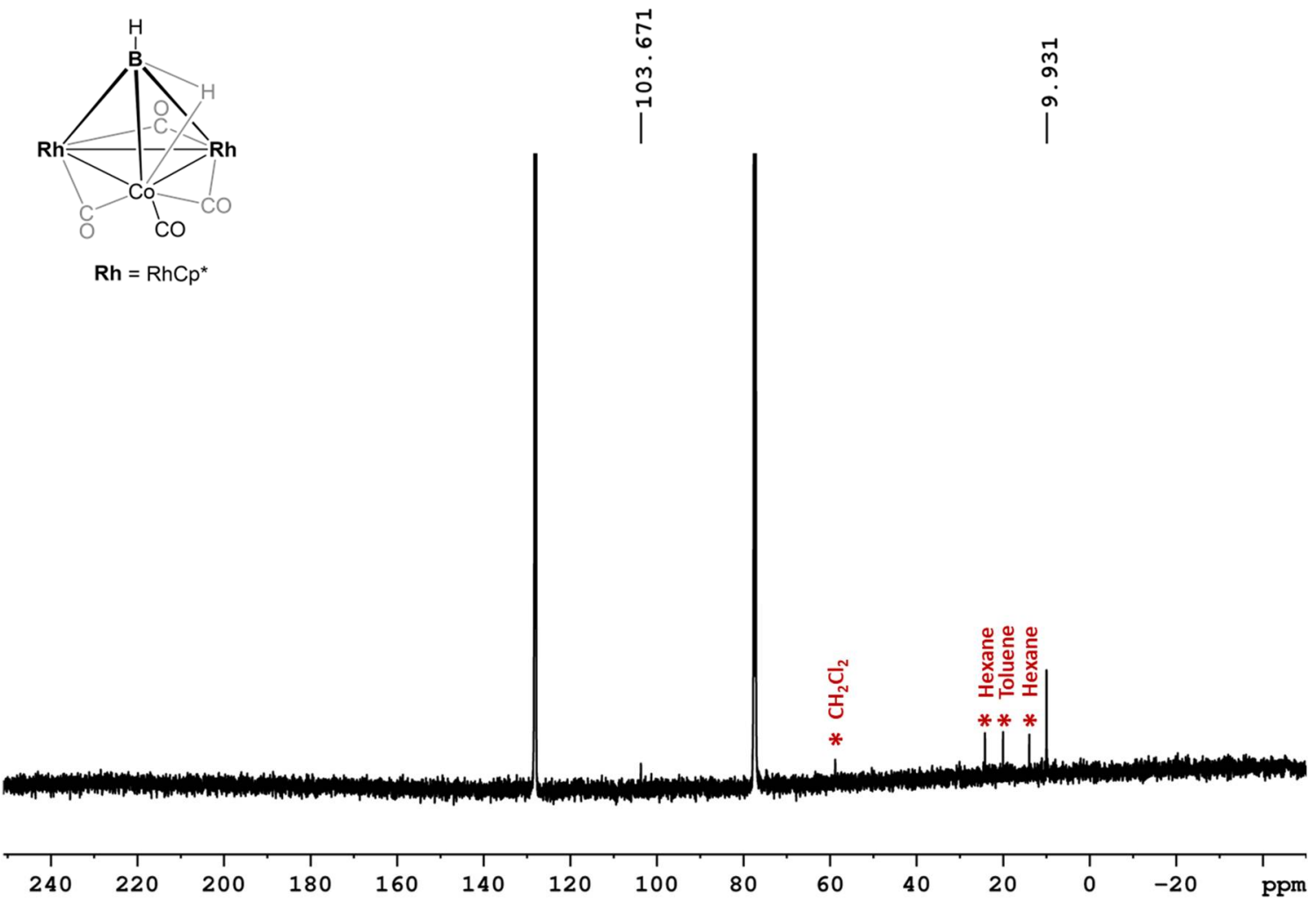

Figure S12. ${ }^{13} \mathrm{C}\left\{{ }^{1} \mathrm{H}\right\}$ NMR spectrum of $\mathbf{3}$ in $\mathrm{CDCl}_{3}$ 


\section{HRMS DST-FIST Funded, Department of Chemistry, IIT Madras}

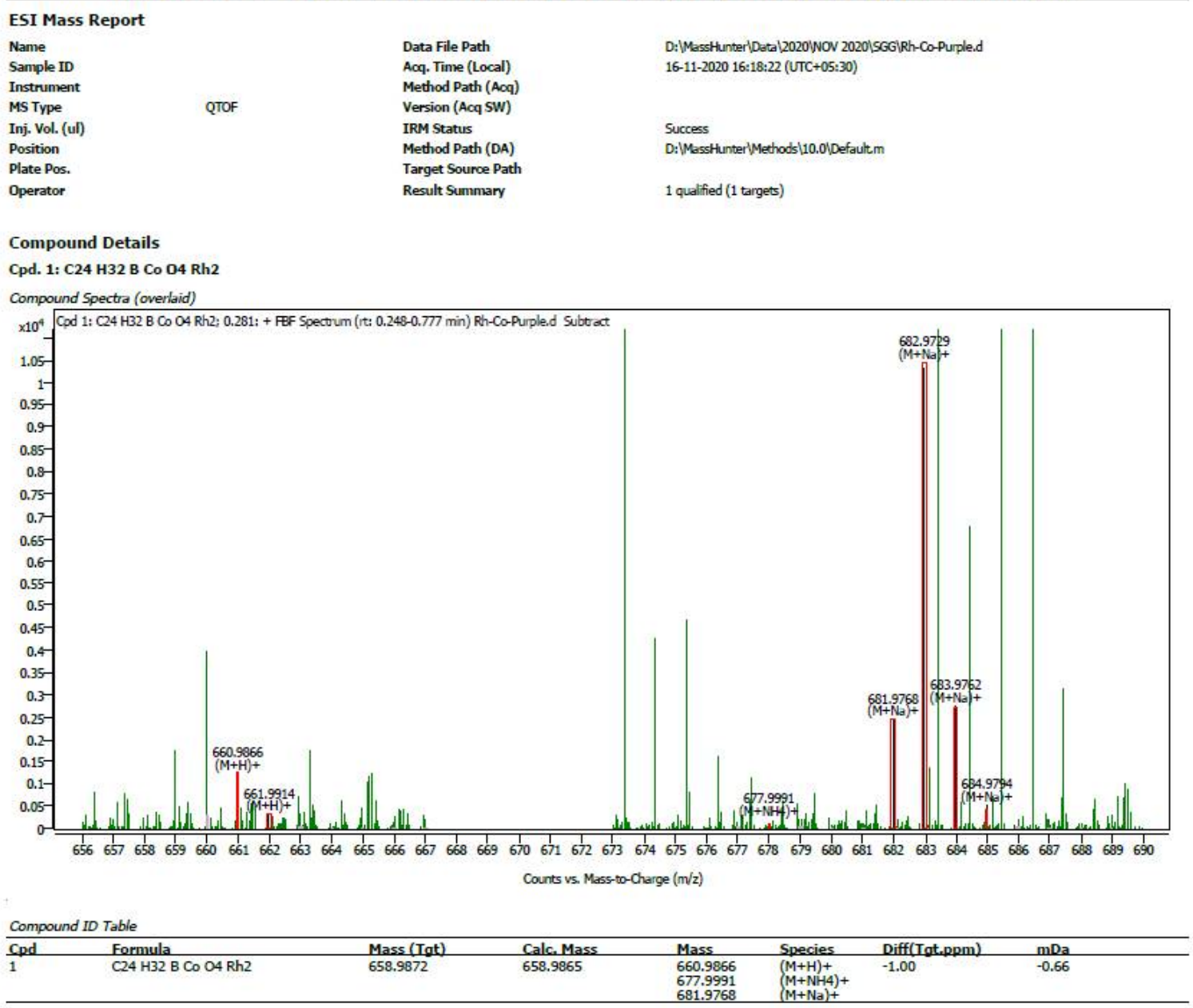

Figure S13. HR-MS spectrum of 3 in $\mathrm{CH}_{2} \mathrm{Cl}_{2}-\mathrm{MeOH}$ mixture

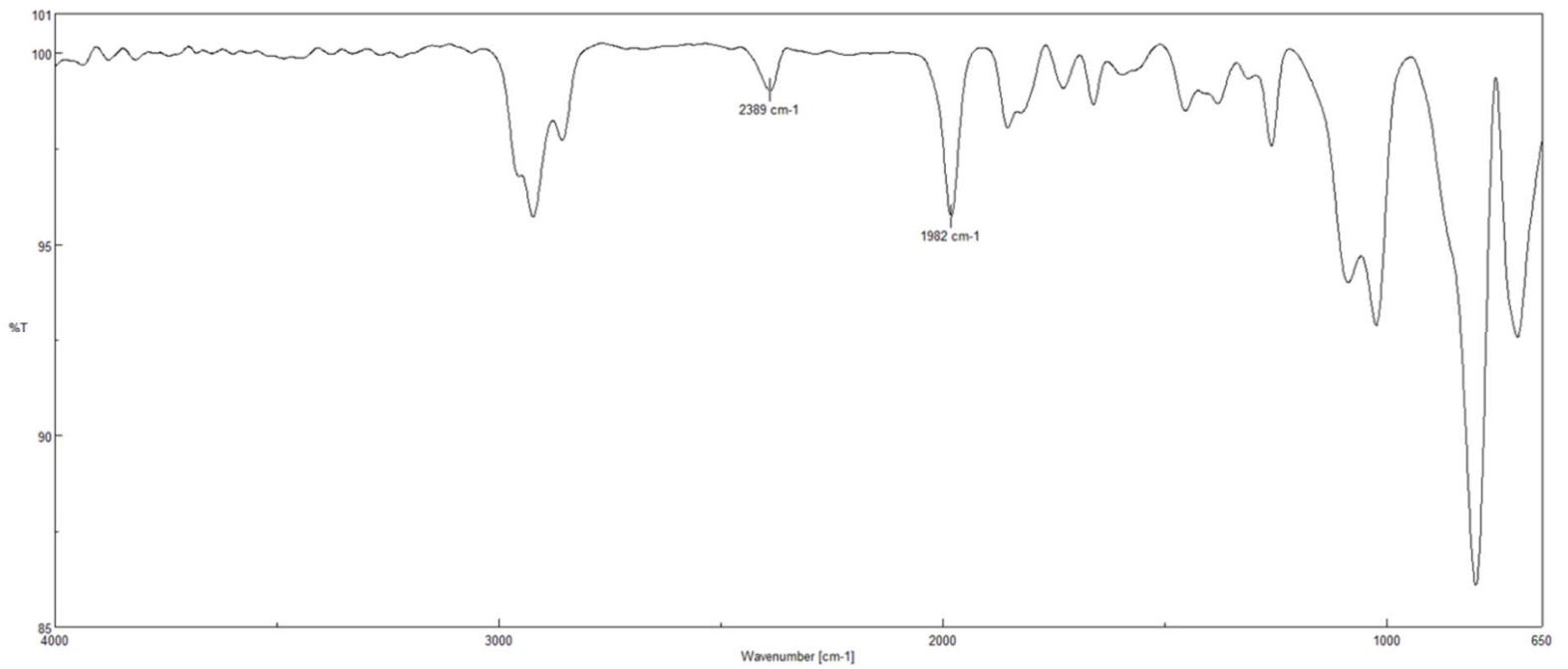

Figure S14. IR spectrum of 3 in $\mathrm{CH}_{2} \mathrm{Cl}_{2}$ 


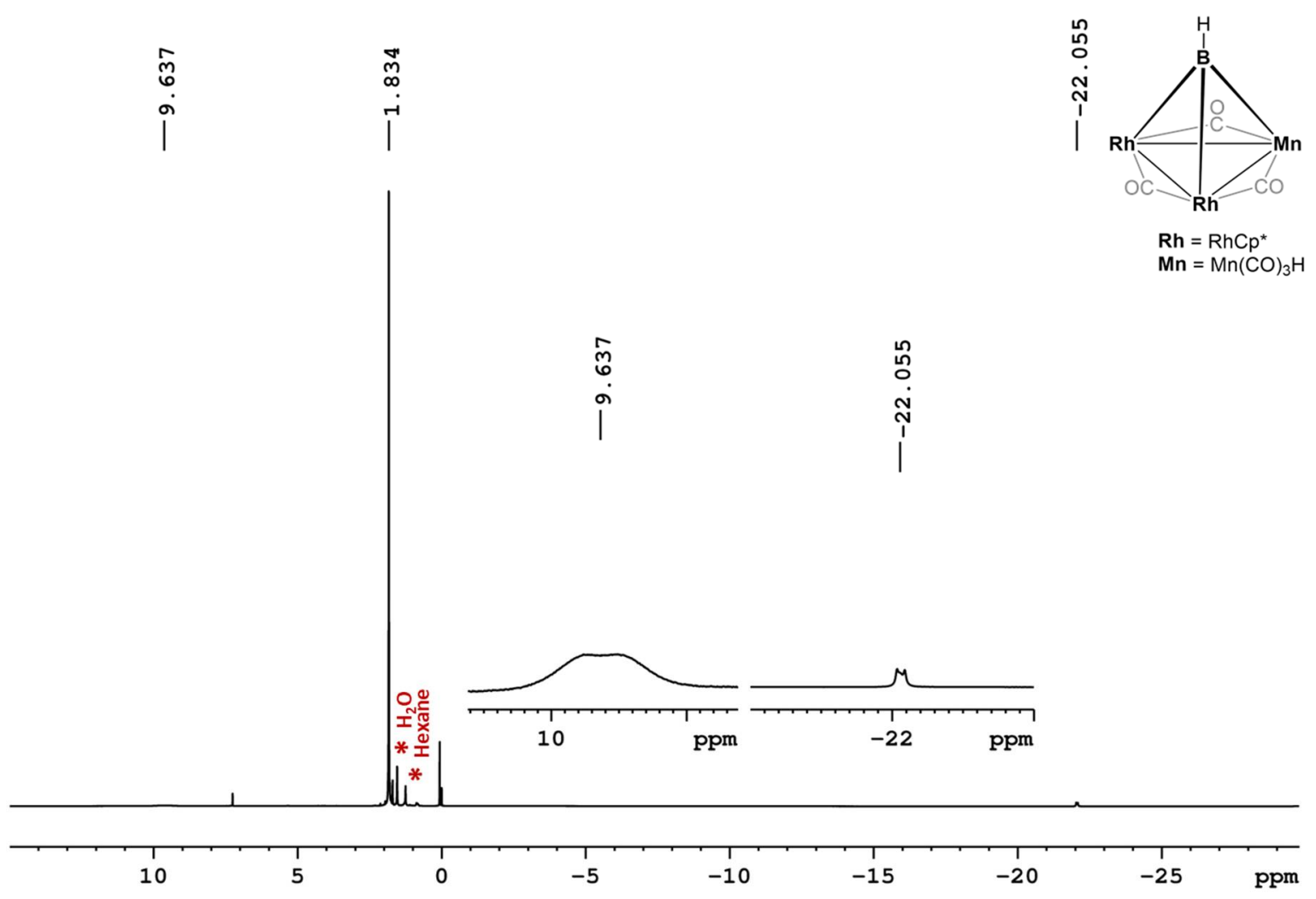

Figure S15. ${ }^{1} \mathrm{H}$ NMR spectrum of 5 in $\mathrm{CDCl}_{3}$

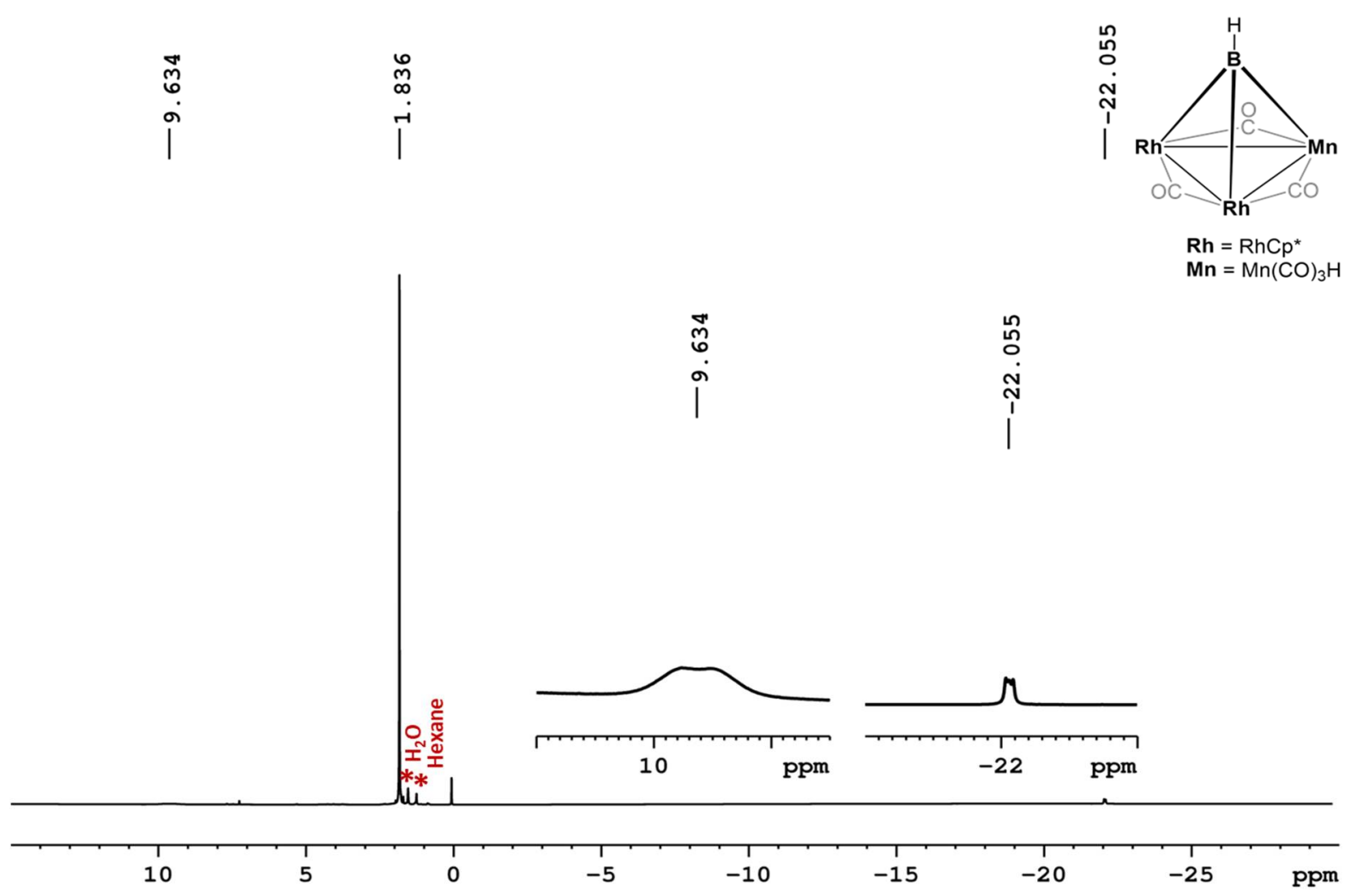

Figure S16. ${ }^{1} \mathrm{H}\left\{{ }^{11} \mathrm{~B}\right\}$ NMR spectrum of 5 in $\mathrm{CDCl}_{3}$ 

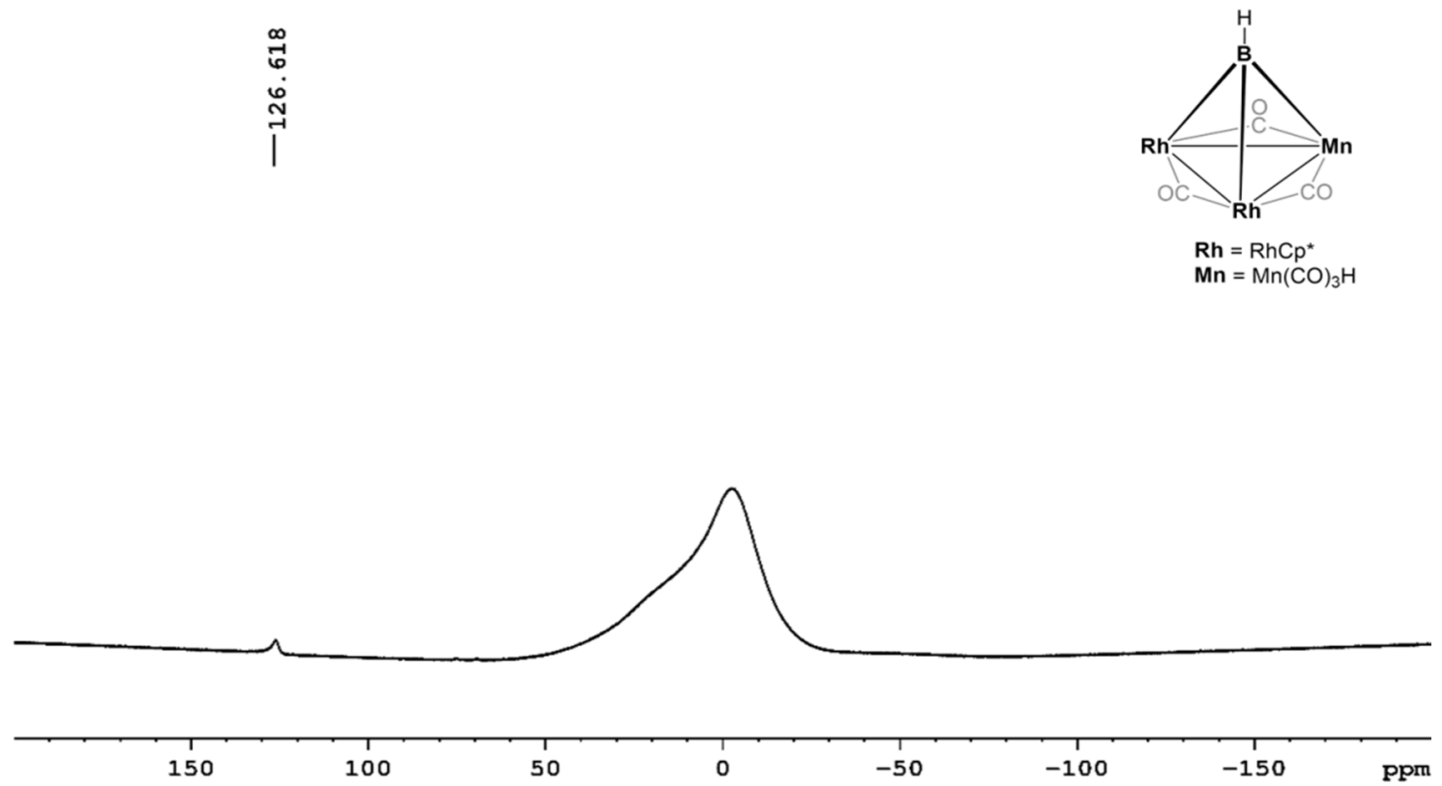

Figure S17. ${ }^{11} \mathrm{~B}\left\{{ }^{1} \mathrm{H}\right\}$ NMR spectrum of 5 in $\mathrm{CDCl}_{3}$

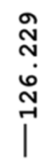

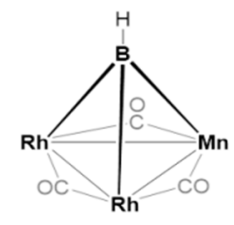

$\mathbf{R h}=\mathrm{RhCp}^{*}$

$\mathrm{Mn}=\mathrm{Mn}(\mathrm{CO})_{3} \mathrm{H}$

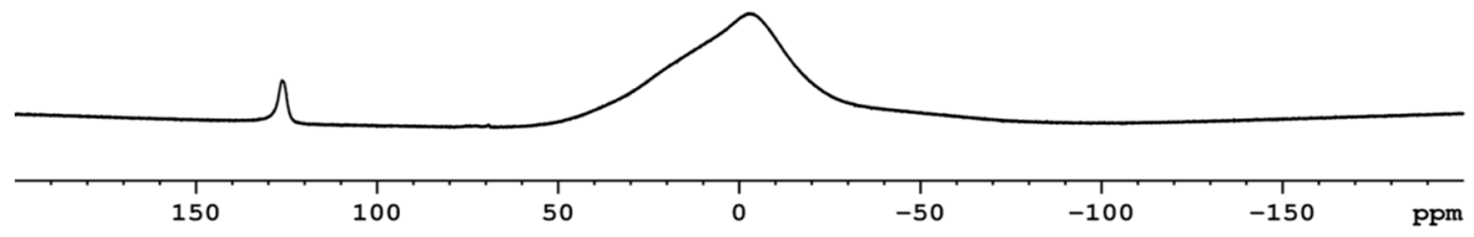

Figure S18. ${ }^{11} \mathrm{~B}$ NMR spectrum of 5 in $\mathrm{CDCl}_{3}$ 

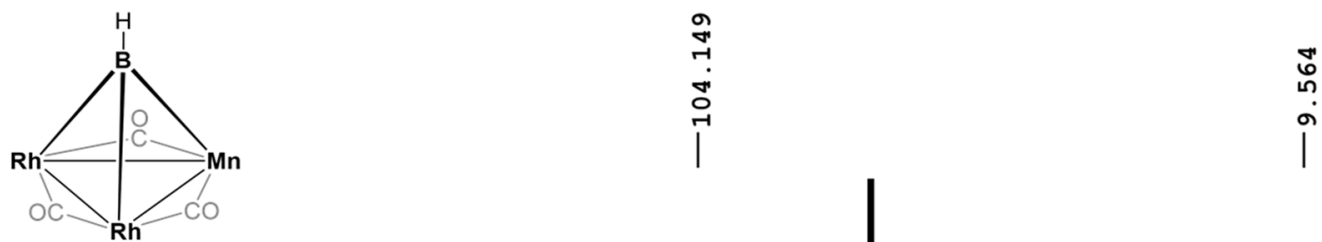

$\mathbf{R h}=\mathrm{RhCp}$

$\mathrm{Mn}=\mathrm{Mn}(\mathrm{CO})_{3} \mathrm{H}$

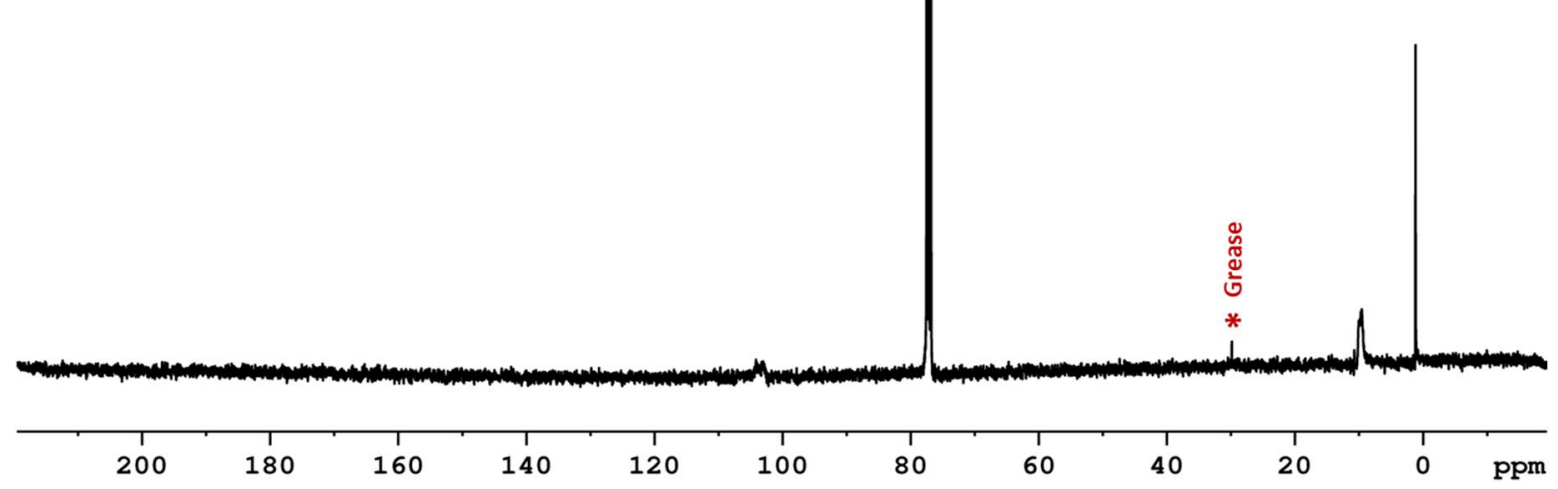

Figure S19. ${ }^{13} \mathrm{C}\left\{{ }^{1} \mathrm{H}\right\}$ NMR spectrum of 5 in $\mathrm{CDCl}_{3}$

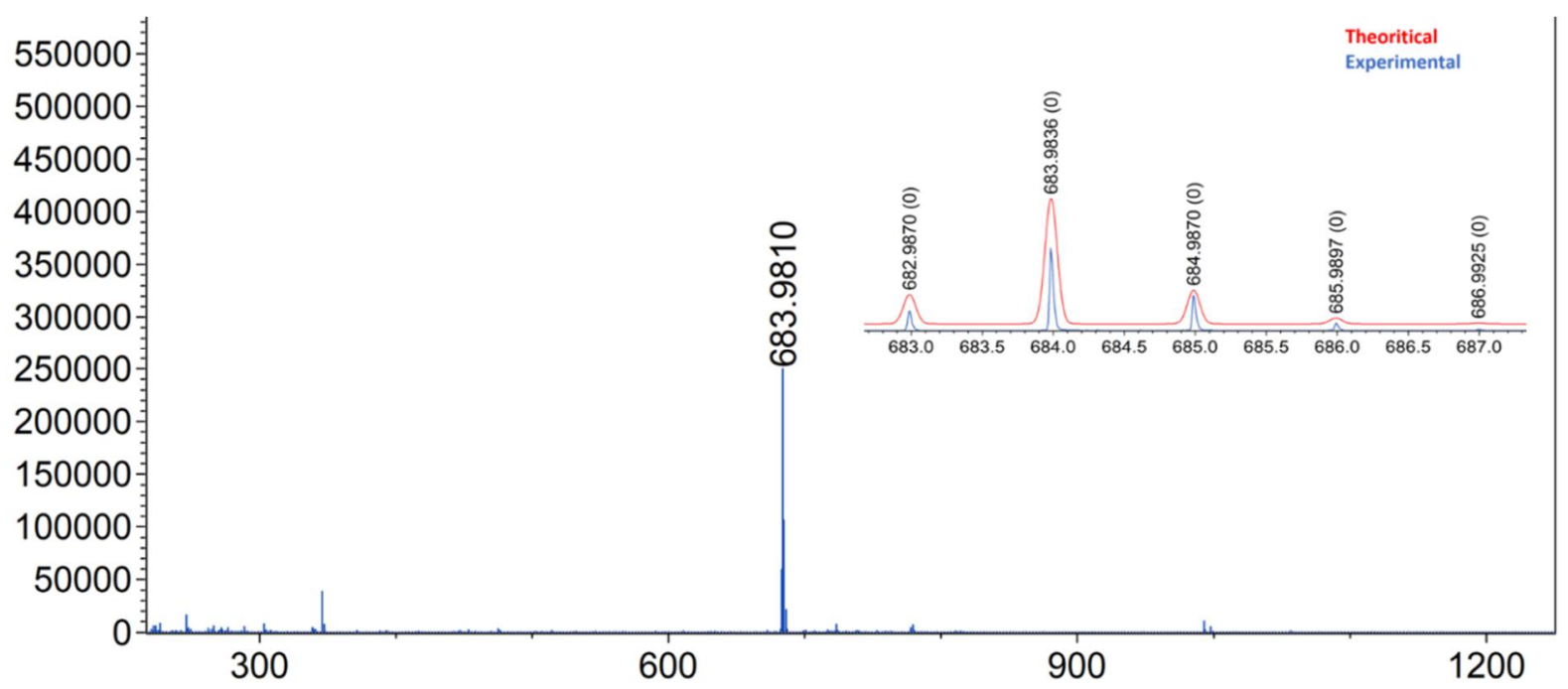

Figure S20. Calculated (red) and experimental (blue) mass spectral isotopic distribution for the fragment of 5 


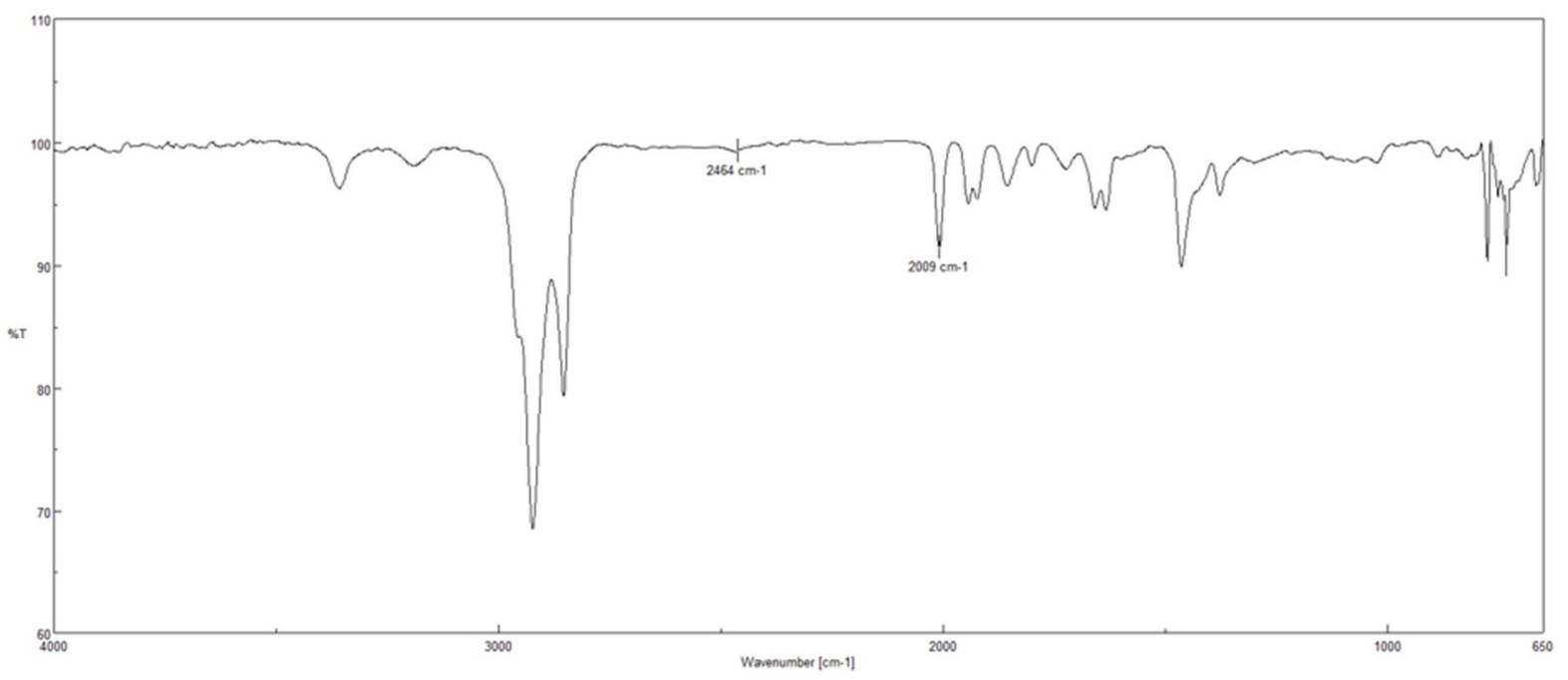

Figure S21. IR spectrum of 5 in $\mathrm{CH}_{2} \mathrm{Cl}_{2}$

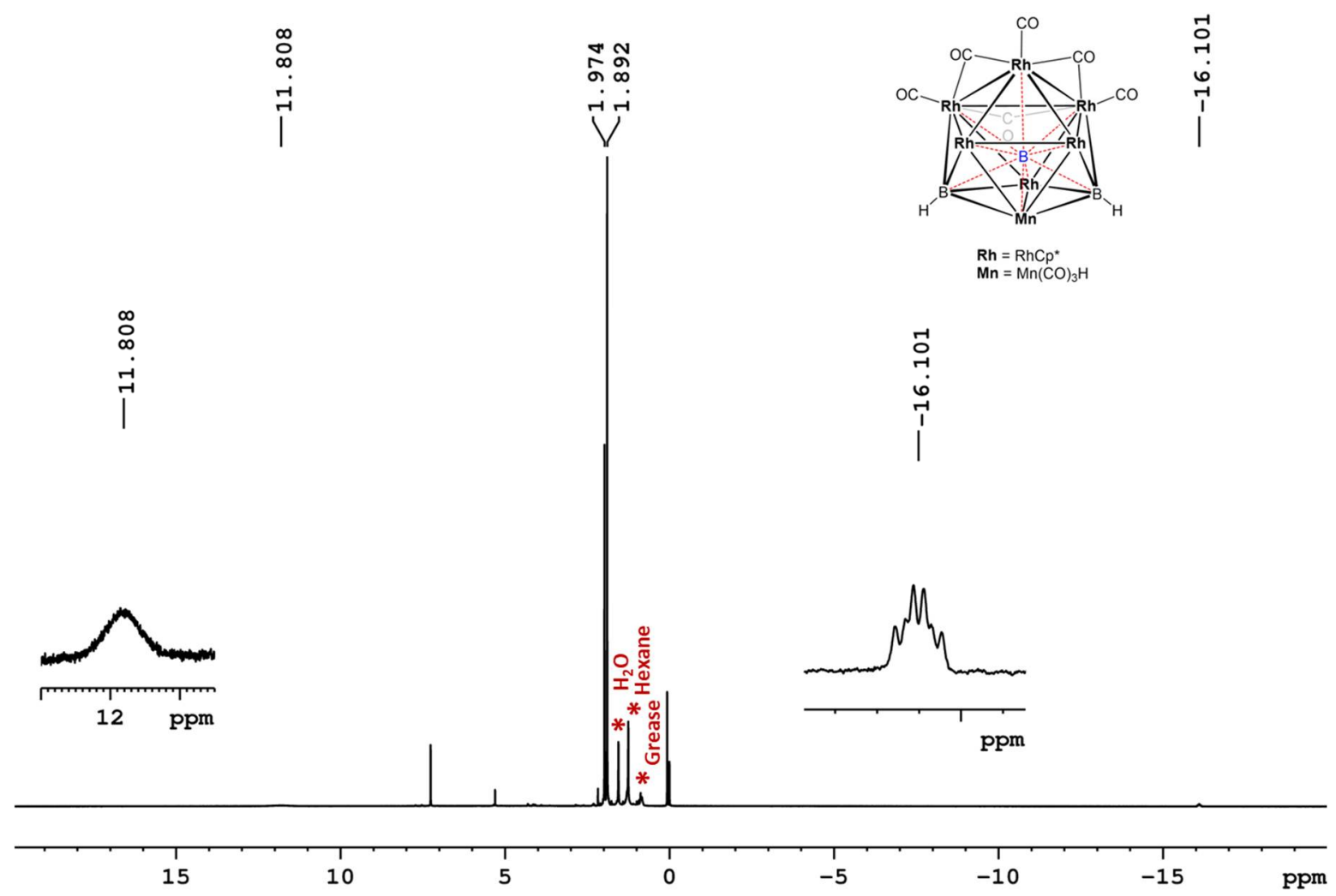

Figure S22. ${ }^{1} \mathrm{H}$ NMR spectrum of 6 in $\mathrm{CDCl}_{3}$ 


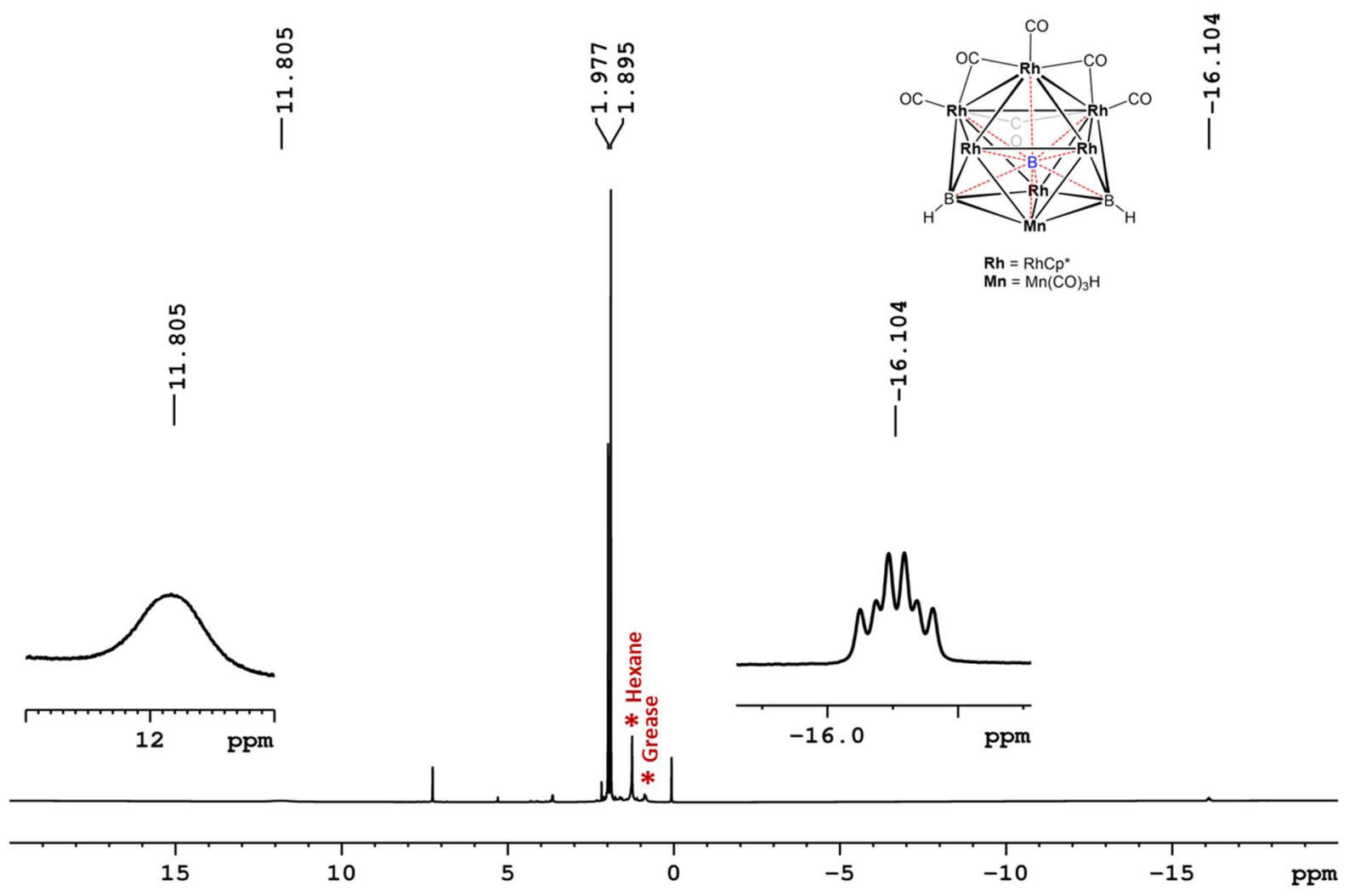

Figure S23. ${ }^{1} \mathrm{H}\left\{{ }^{11} \mathrm{~B}\right\} \mathrm{NMR}$ spectrum of $\mathbf{6}$ in $\mathrm{CDCl}_{3}$
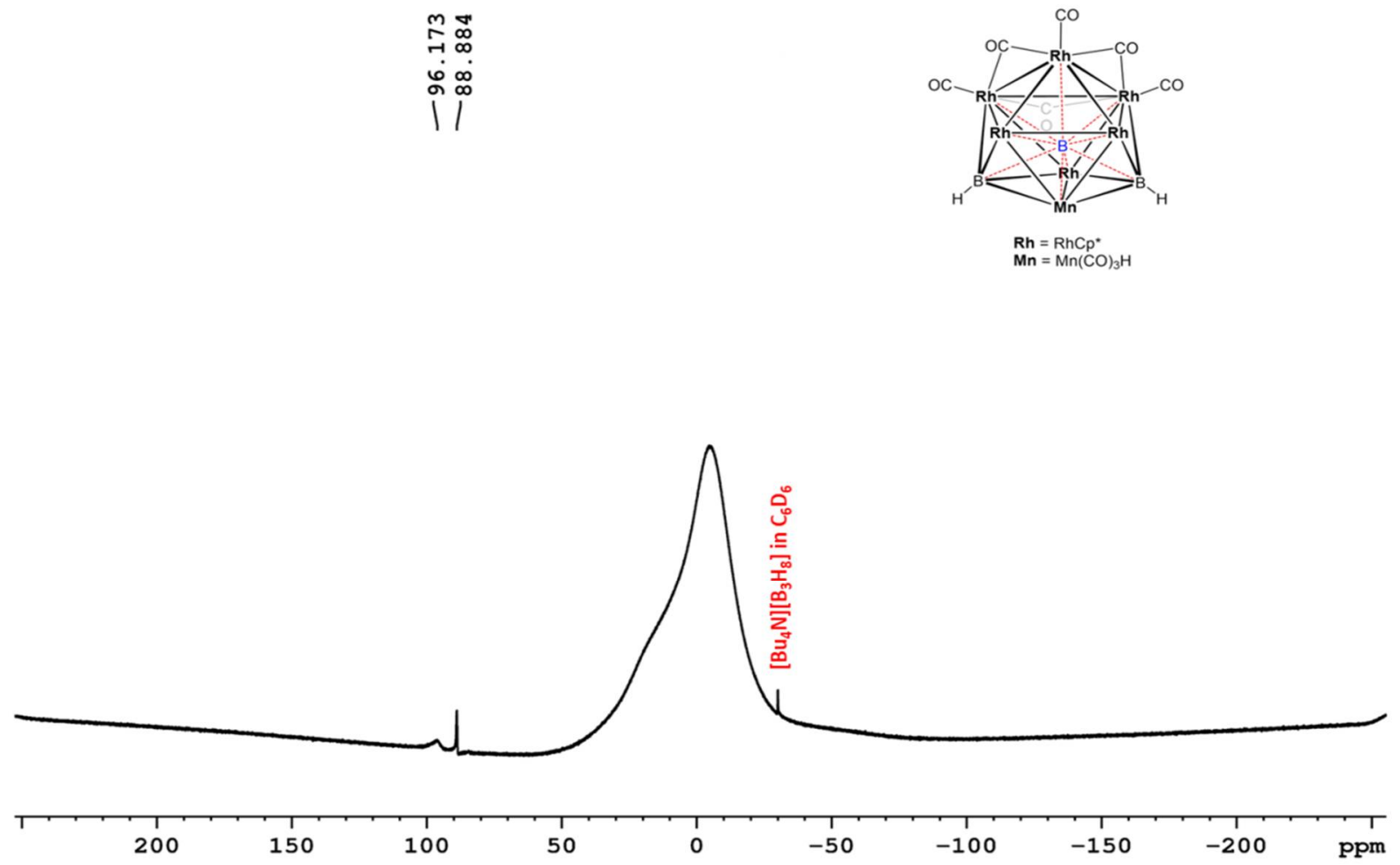

Figure S24. ${ }^{11} \mathrm{~B}\left\{{ }^{1} \mathrm{H}\right\}$ NMR spectrum of 6 in $\mathrm{CDCl}_{3}$ 

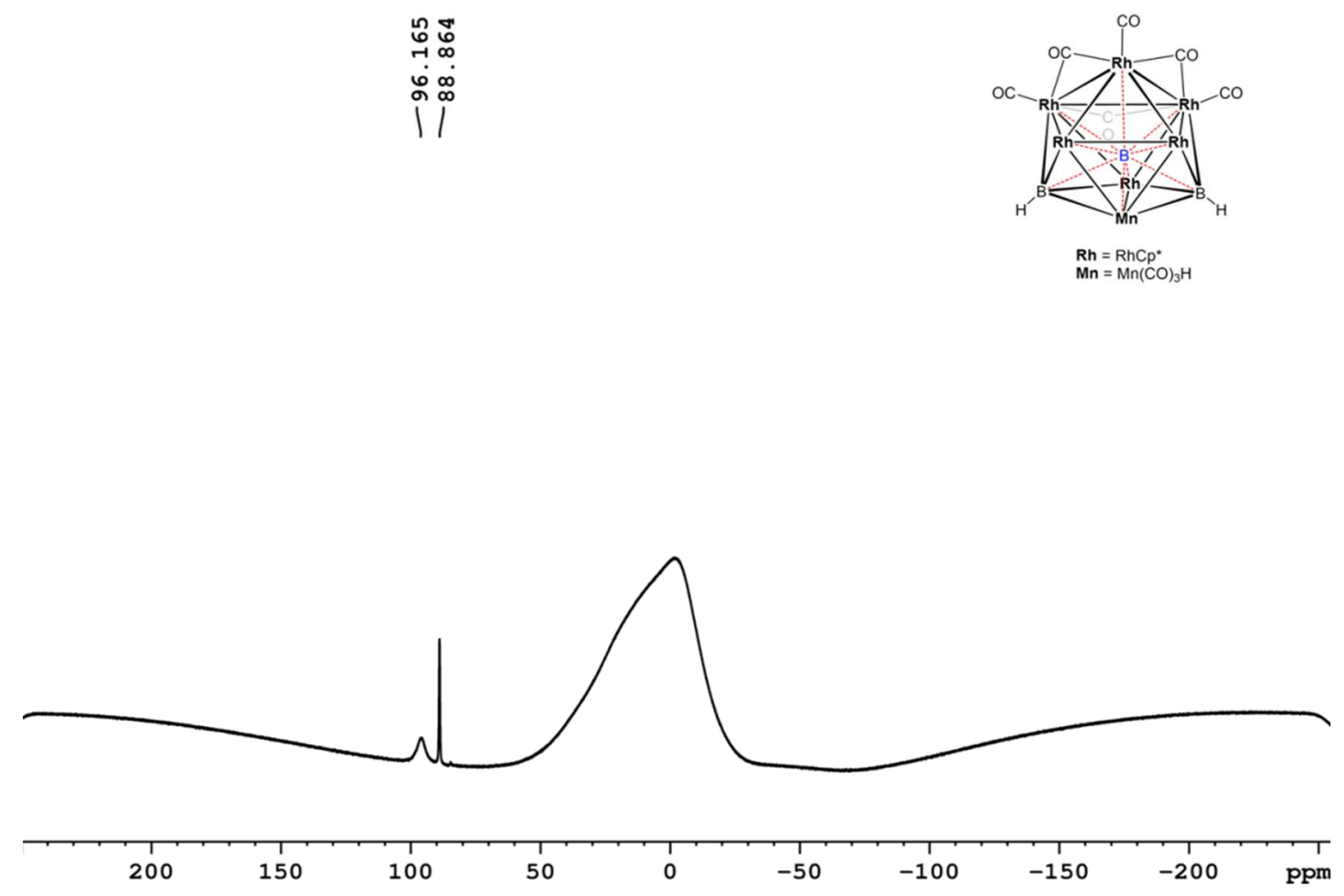

Figure S25. ${ }^{11} \mathrm{~B}$ NMR spectrum of 6 in $\mathrm{CDCl}_{3}$

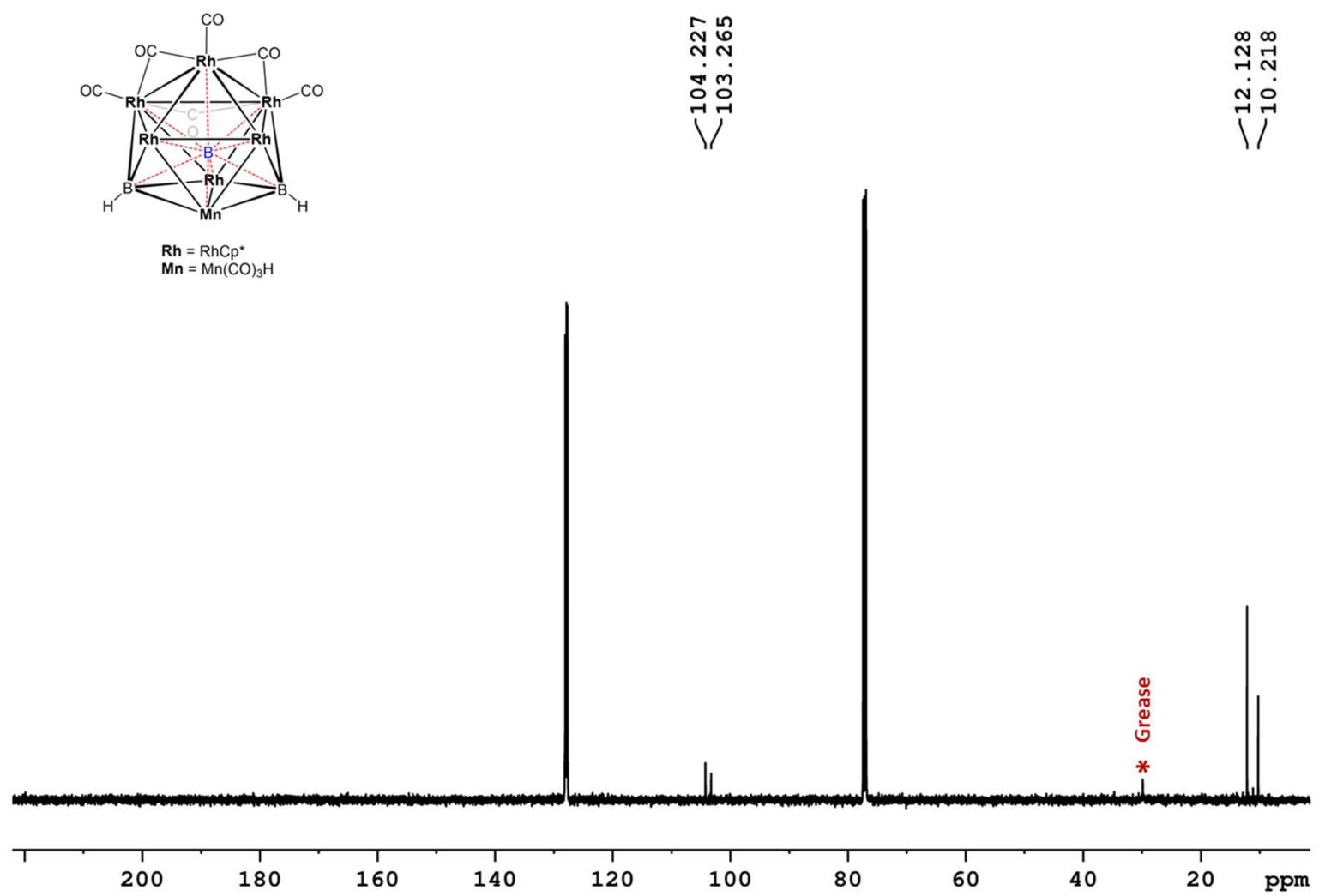

Figure S26. ${ }^{13} \mathrm{C}\left\{{ }^{1} \mathrm{H}\right\}$ NMR spectrum of 6 in $\mathrm{CDCl}_{3}$ 


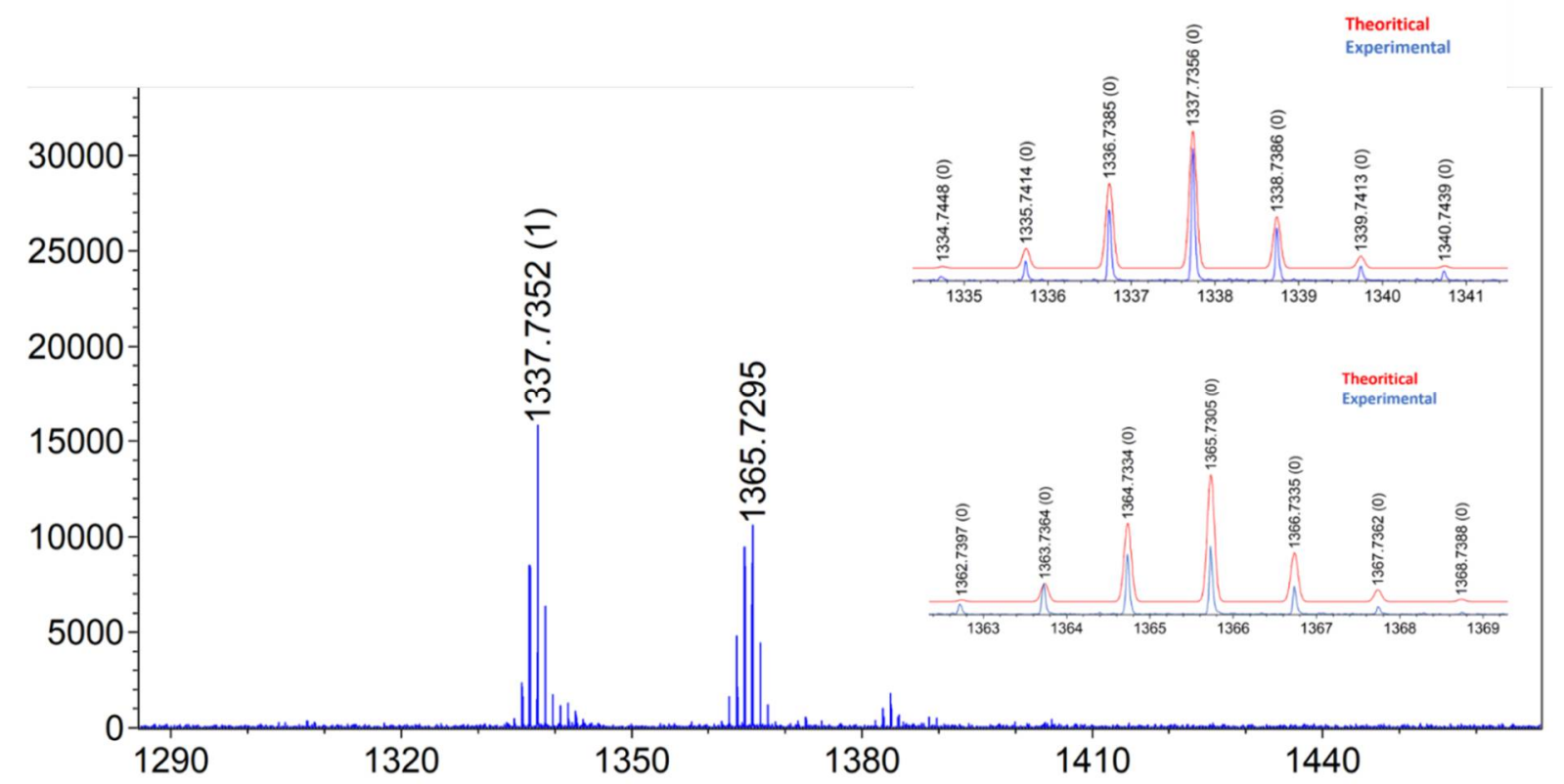

Figure S27. Calculated (red) and experimental (blue) mass spectral isotopic distribution for the fragments of $\mathbf{6}$

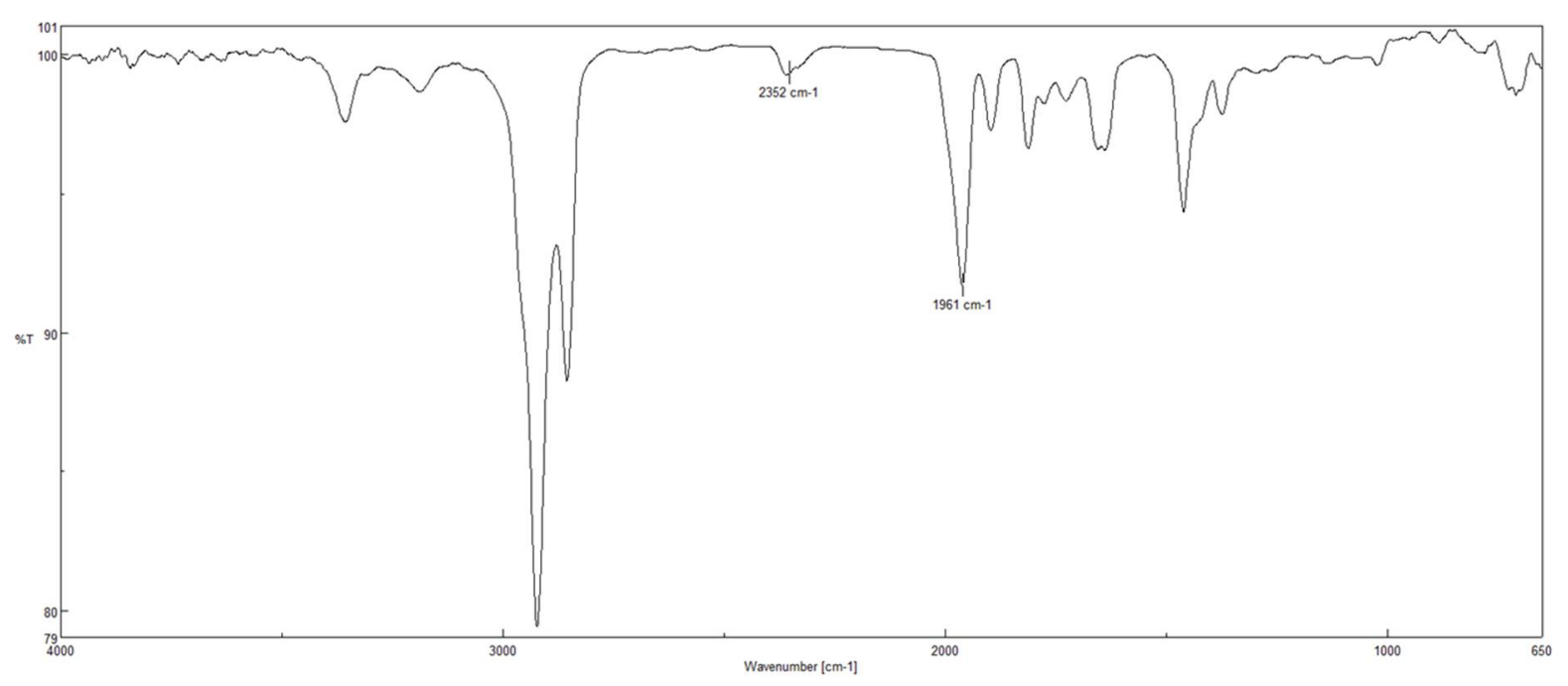

Figure S28. IR spectrum of 6 in $\mathrm{CH}_{2} \mathrm{Cl}_{2}$ 

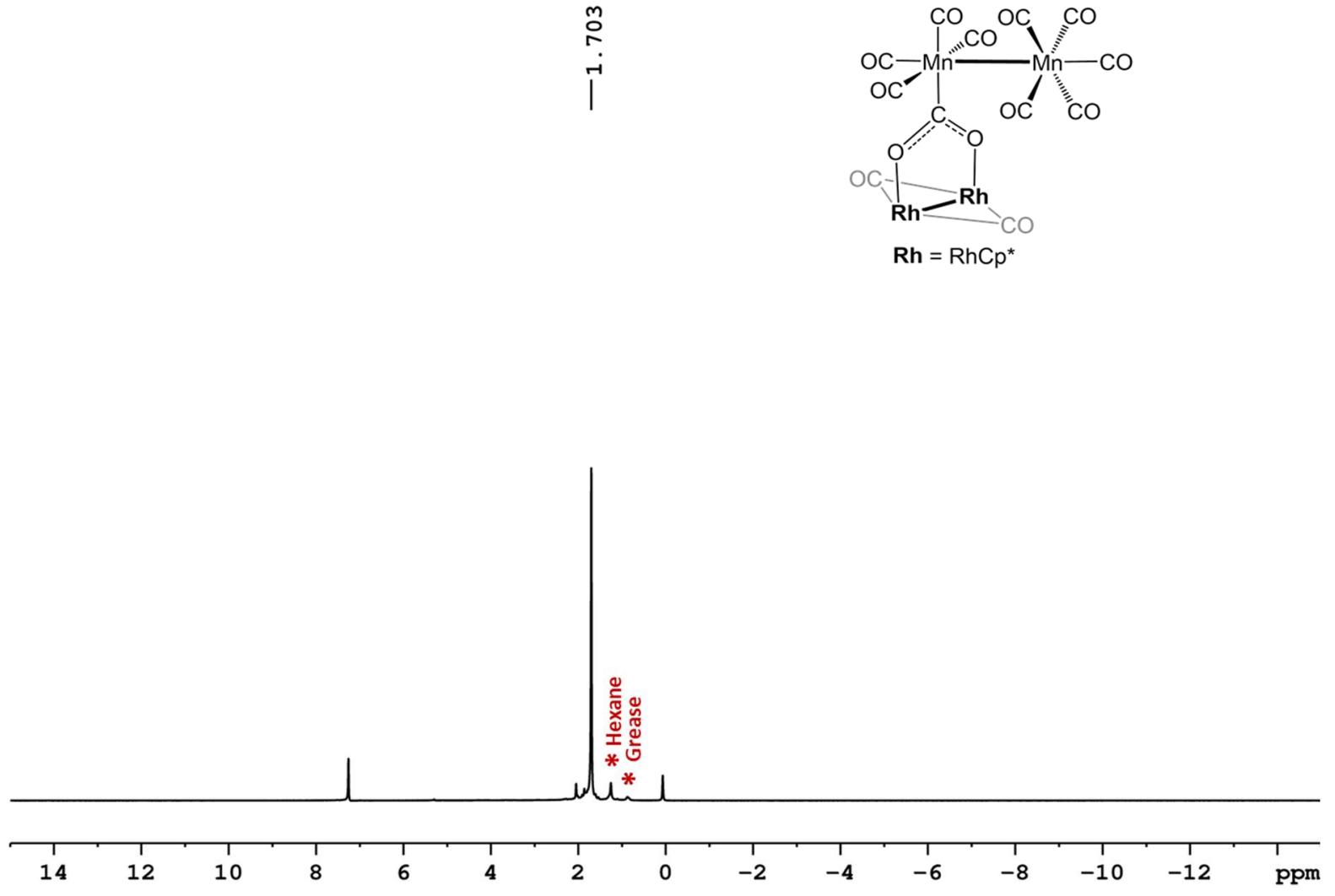

Figure S29. ${ }^{1} \mathrm{H}$ NMR spectrum of 8 in $\mathrm{CDCl}_{3}$

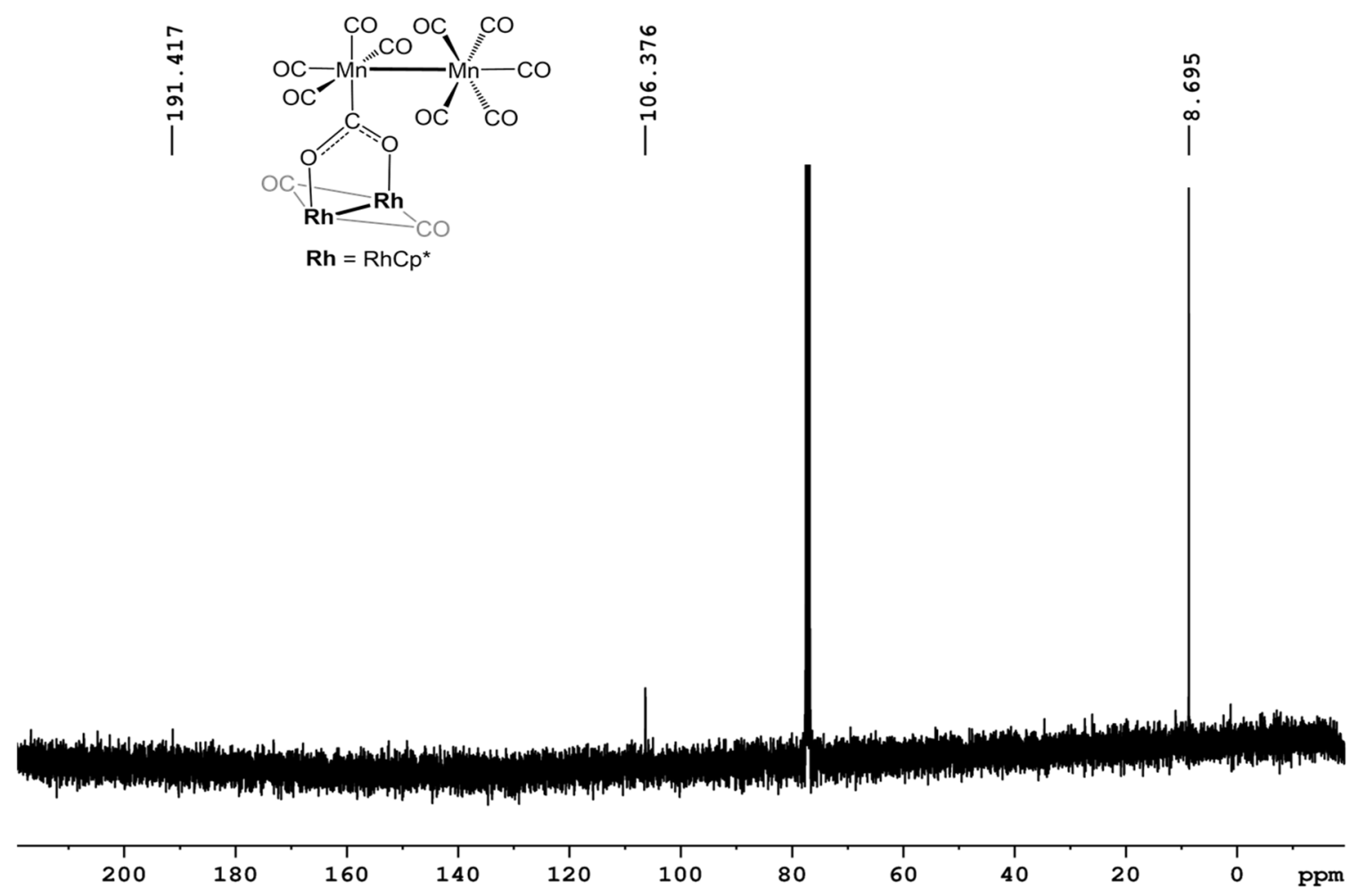

Figure S30. ${ }^{13} \mathrm{C}\left\{{ }^{1} \mathrm{H}\right\}$ NMR spectrum of 8 in $\mathrm{CDCl}_{3}$ 


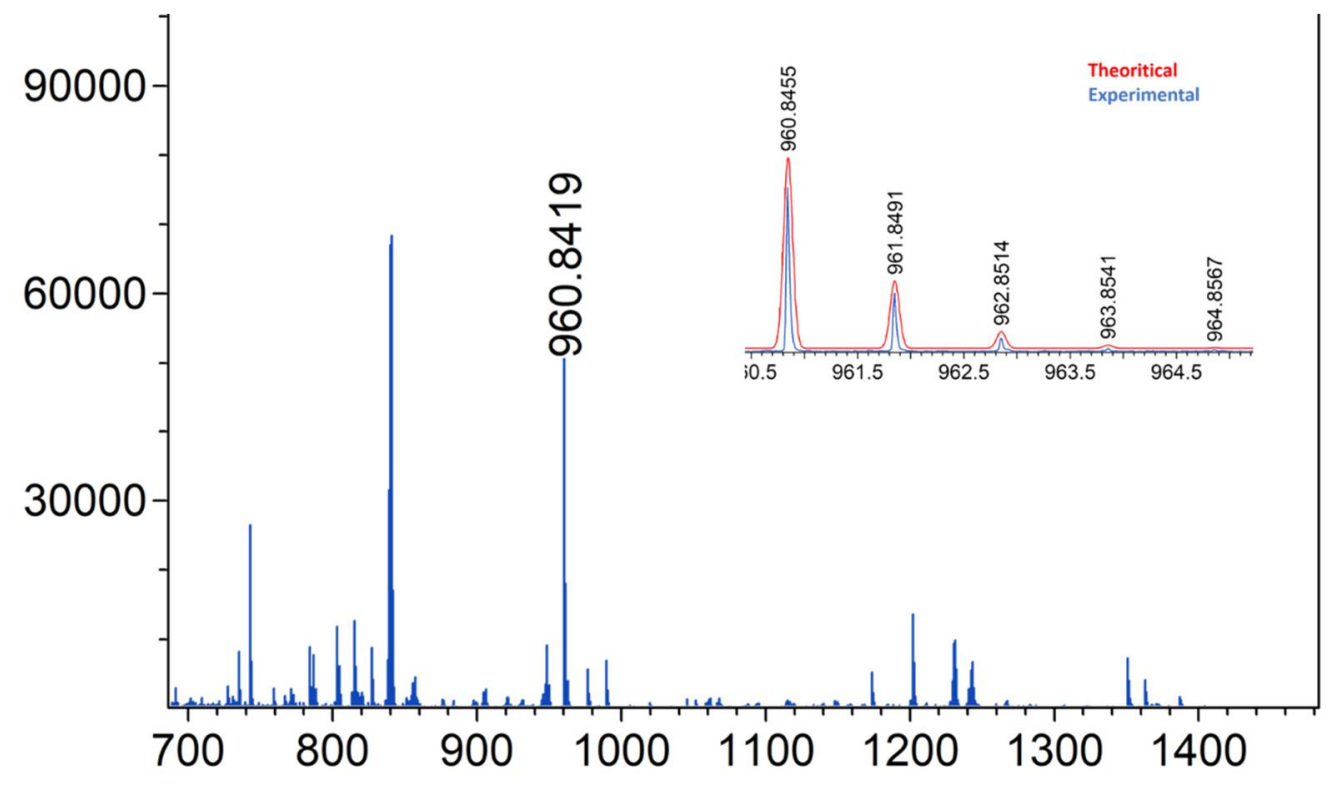

Figure S31. Calculated (red) and experimental (blue) mass spectral isotopic distribution for the fragment of $\mathbf{8}$

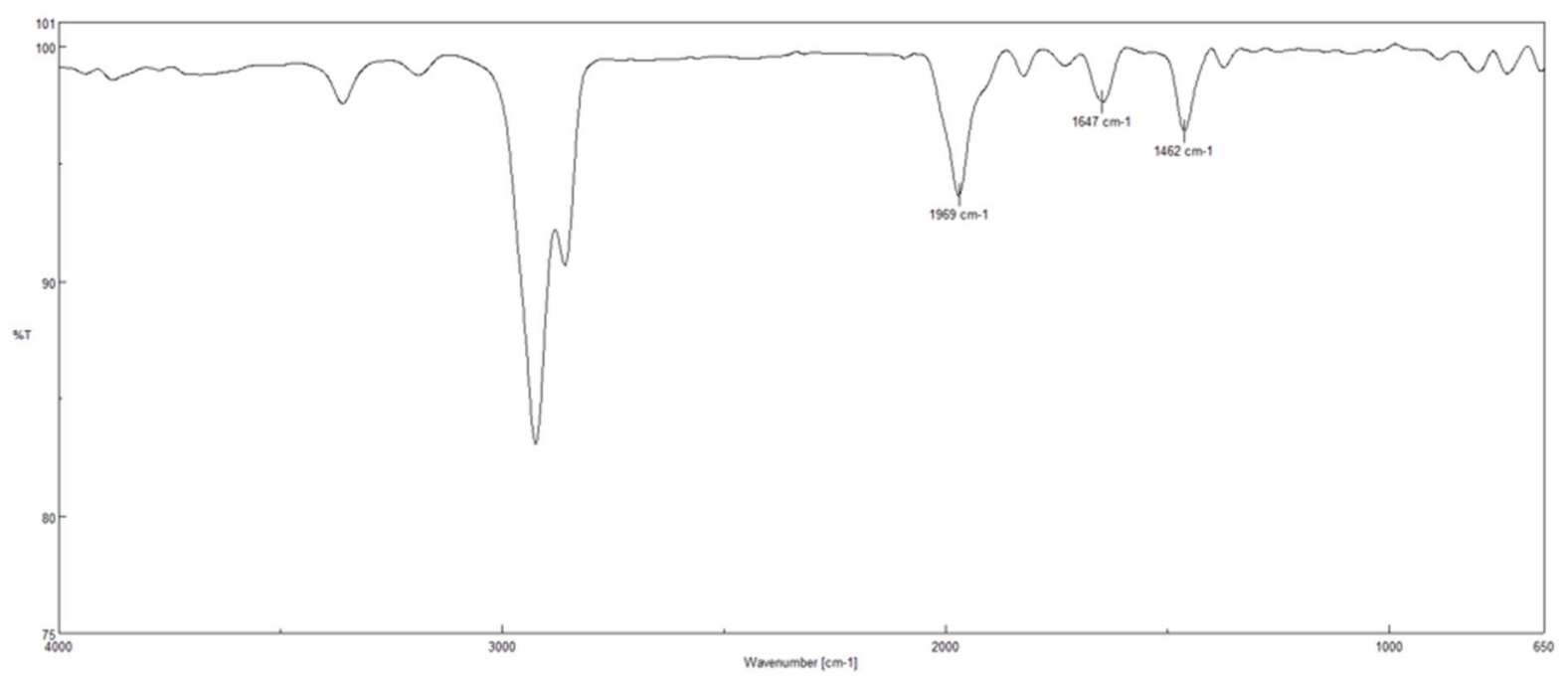

Figure S32. IR spectrum of 8 in $\mathrm{CH}_{2} \mathrm{Cl}_{2}$ 


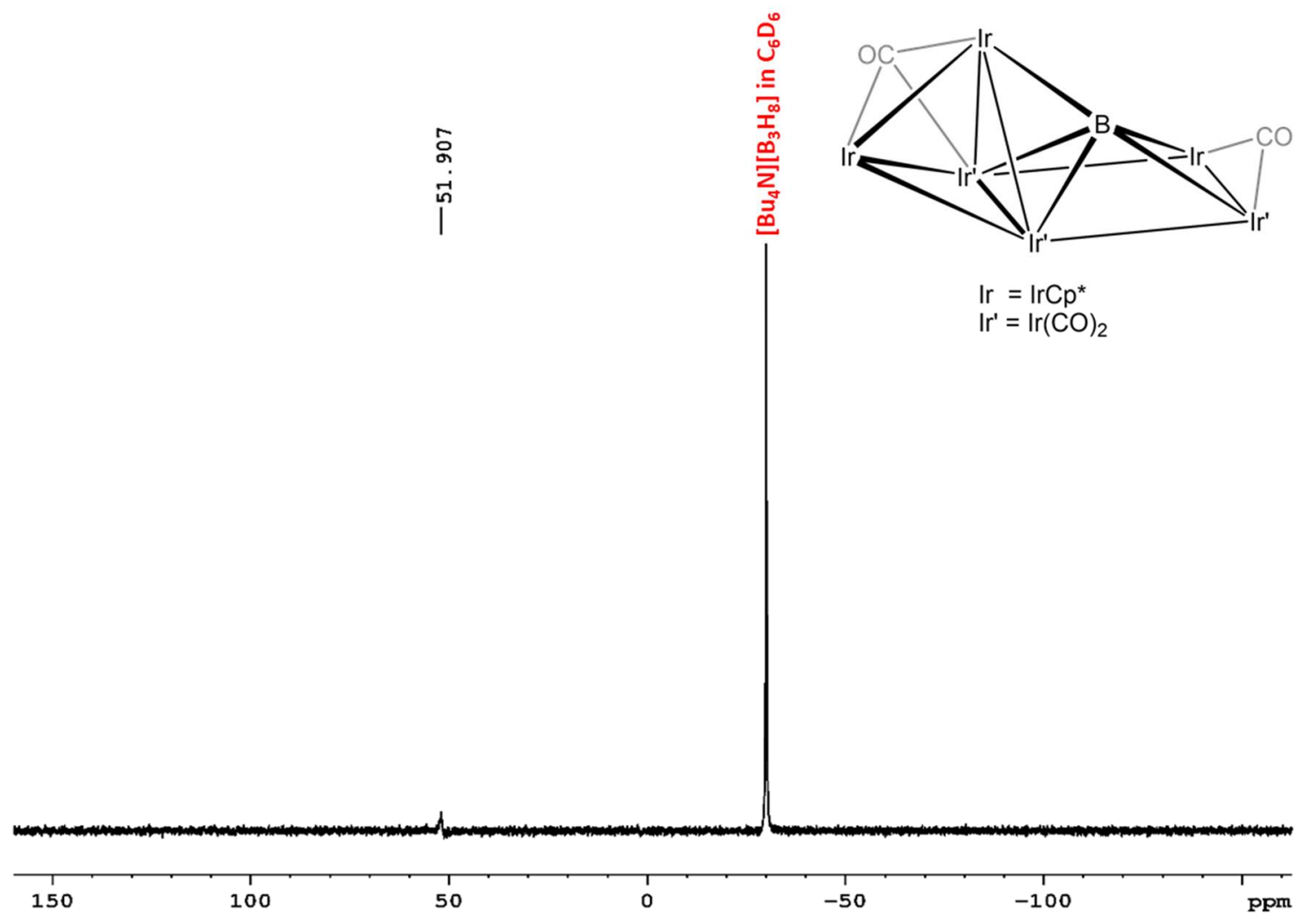

Figure S33. ${ }^{11} \mathrm{~B}\left\{{ }^{1} \mathrm{H}\right\}$ NMR spectrum of 10 in $\mathrm{CDCl}_{3}{ }^{1}$

\section{Computational Details}

All molecules were fully optimized with the Gaussian $09^{2}$ program using bp 86 functional in conjunction with the 6-31g(d)-sdd basis set. The model compounds were fully optimized in gaseous state (no solvent effect) starting from the X-ray crystallographic coordinates. The calculations were performed with the $\mathrm{Cp}$ analogues instead of $\mathrm{Cp}^{*}$ to save computing time. Frequency calculations were performed at the same level of theory to verify the nature of the stationary state and the absence of any imaginary frequency confirmed that all structures represent minima on the potential energy hypersurface. The GIAO ${ }^{3}$ method was employed for the calculations of ${ }^{11} \mathrm{~B}$ chemical shifts. The bp86/6-31g(d)-sdd optimized structures has been used for calculating the NMR chemical shifts by means of the hybrid B3LYP $\mathrm{P}^{4}$ and 6-31g(d)sdd. With respect to $\mathrm{B}_{2} \mathrm{H}_{6}$, the ${ }^{11} \mathrm{~B}$ NMR chemical shifts has been computed (shielding constant $93.5 \mathrm{ppm})$ and changed to $\left[\mathrm{BF}_{3} \cdot \mathrm{OEt}_{2}\right]$ scale utilizing the experimental $\delta\left({ }^{11} \mathrm{~B}\right)$ value of $\mathrm{B}_{2} \mathrm{H}_{6}$ (16.6 ppm). Natural bonding analyses were performed with the natural bond orbital (NBO) partitioning scheme as implemented in the Gaussian 09 suite of programs. Wiberg bond indexes (WBI) were obtained on natural bond orbital analysis. All the optimized structures and orbital graphics were generated using the Gaussview ${ }^{3}$ and Chemcraft $^{4}$ visualization programs. 
III. Electronic Structure Analysis

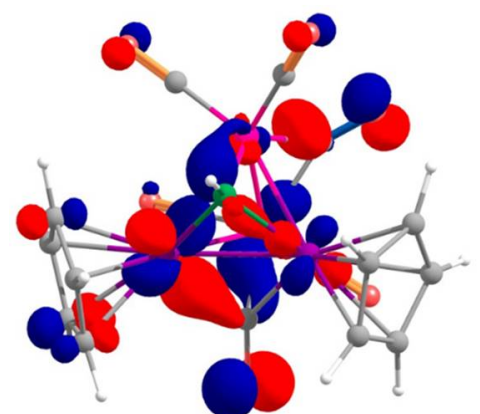

HOMO

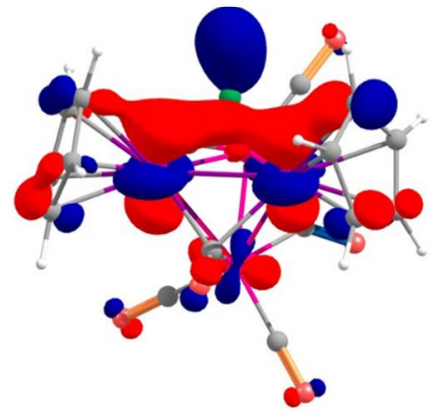

HOMO-14

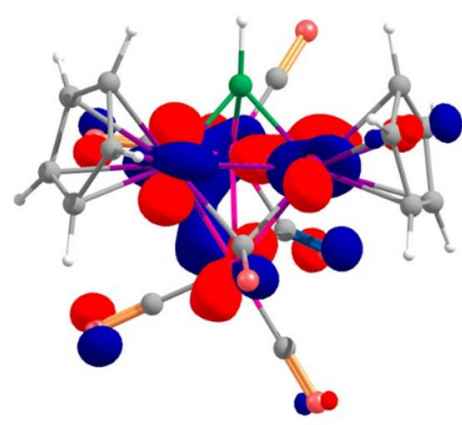

HOMO-12

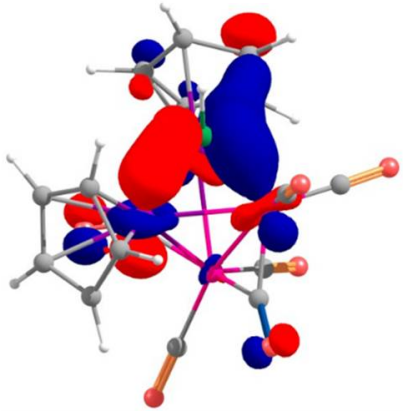

HOMO-15

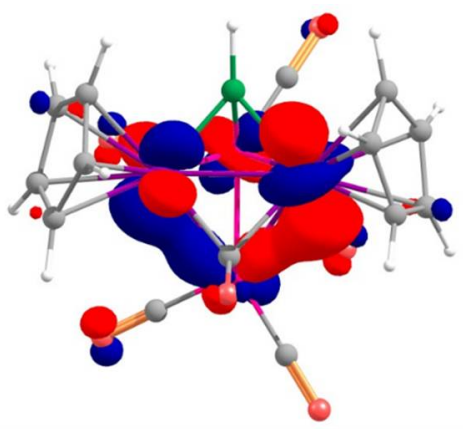

HOMO-13

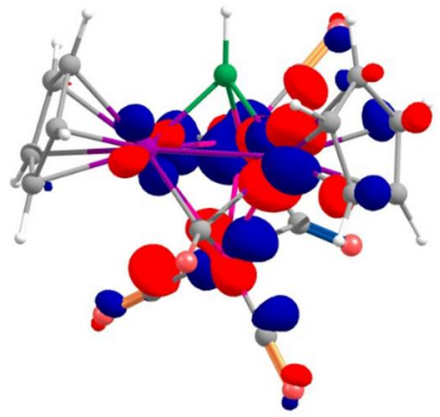

LUMO

Figure S34. Selected frontier molecular orbitals of 2.

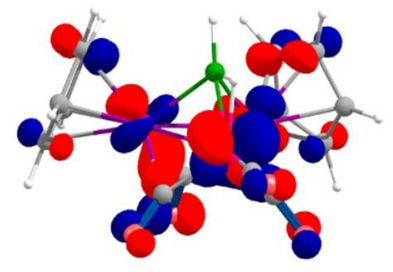

HOMO

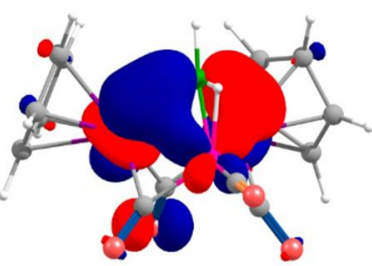

HOMO-11

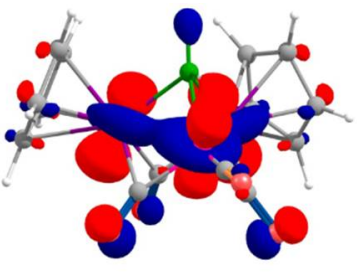

HOMO-7

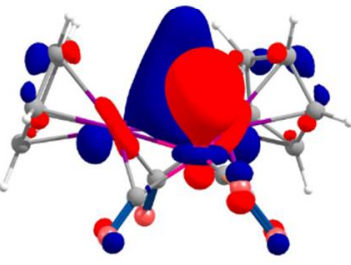

HOMO-16

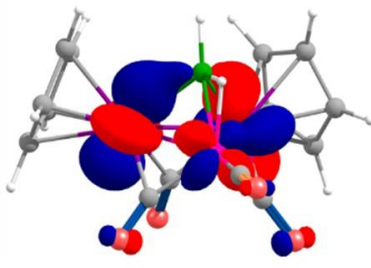

HOMO-8

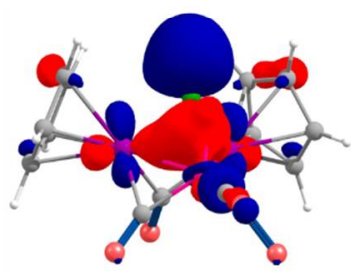

HOMO-17

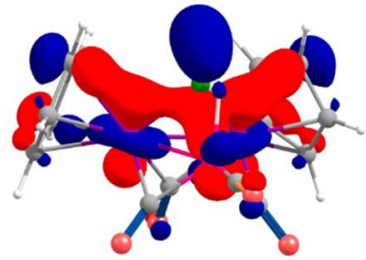

HOMO-10

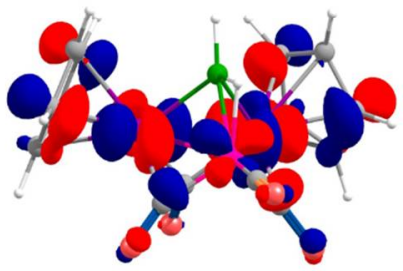

LUMO

Figure S35. Selected frontier molecular orbitals of $\mathbf{3}$. 


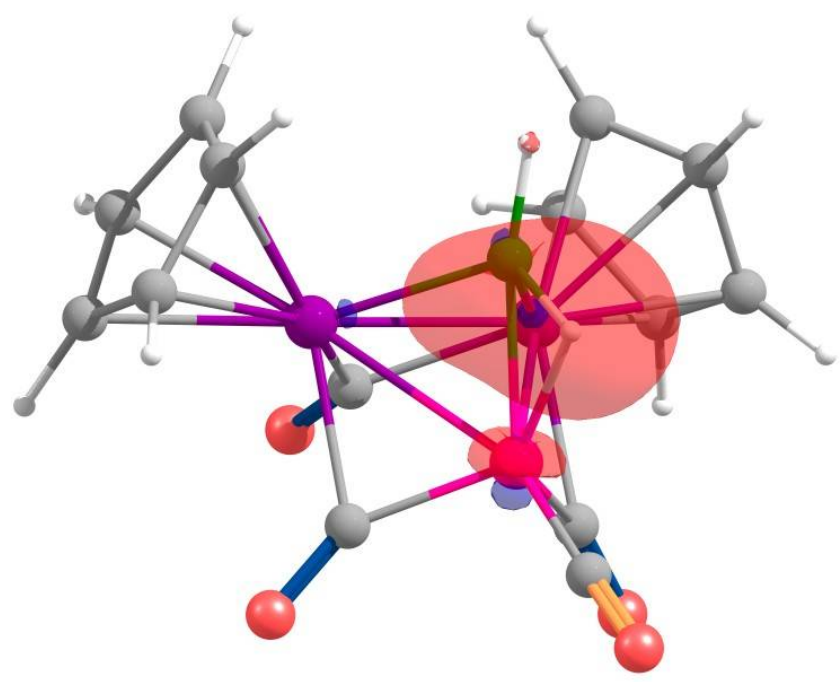

Figure S36. NBO donor-acceptor interaction between B-H bonds and Co centres in $\mathbf{3}$.

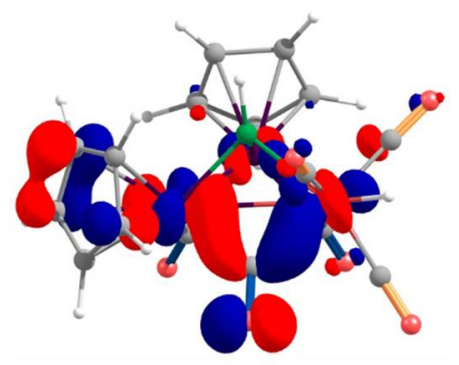

HOMO

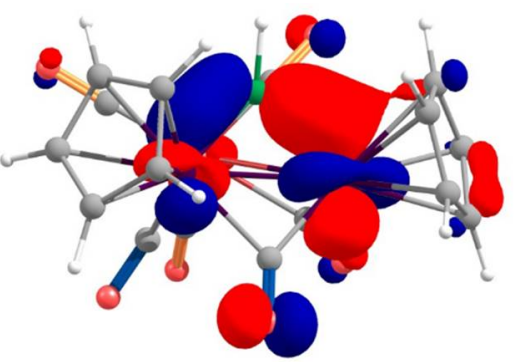

HOMO-10

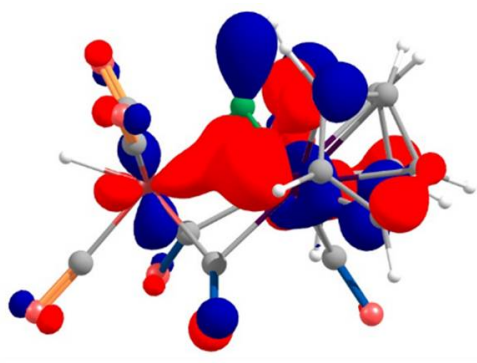

HOMO-8

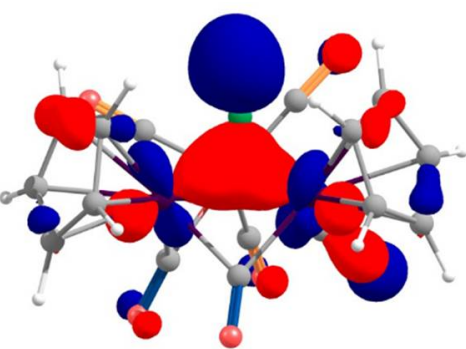

HOMO-16

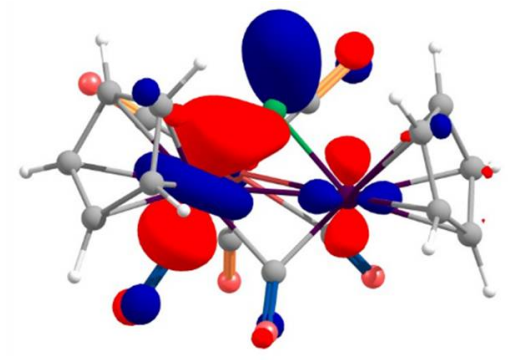

HOMO-9

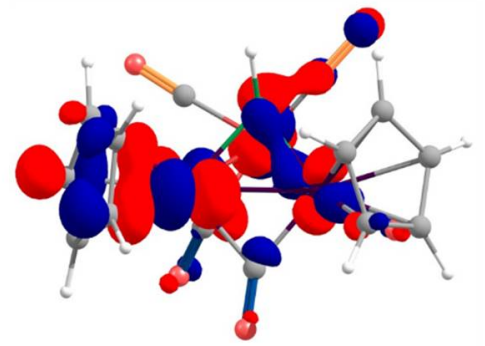

LUMO

Figure S37. Selected frontier molecular orbitals of 5. 
Table S1. Calculated natural charges ( $\mathrm{q}_{\mathrm{M}}$ and $\mathrm{q}_{\mathrm{B}}$ ), natural valence population (Pop) and HOMO-LUMO gaps of 2, 3, 5, 6 and $\mathbf{1 0}$

\begin{tabular}{|c|c|c|c|c|c|}
\hline & $\mathrm{q}_{\mathrm{M}}$ & $\mathrm{q}_{\mathrm{B}}$ & Pop $\left(\mathrm{M}_{\mathrm{val}}\right)$ & Pop $\left(B_{\mathrm{val}}\right)$ & $\Delta \mathrm{E}_{\mathrm{H}-\mathrm{L}}(\mathrm{eV})$ \\
\hline \multirow[t]{4}{*}{2} & $-0.355(\mathrm{Rh})$ & 0.193 & $9.343(\mathrm{Rh})$ & 2.778 & 1.651 \\
\hline & $-0.326(\mathrm{Rh})$ & & $9.312(\mathrm{Rh})$ & & \\
\hline & $-0.259(\mathrm{Co})$ & & $9.281(\mathrm{Co})$ & & \\
\hline & $-0.195(\mathrm{Co})$ & & $9.217(\mathrm{Co})$ & & \\
\hline \multirow[t]{3}{*}{3} & $-0.367(\mathrm{Rh})$ & 0.017 & $9.357(\mathrm{Rh})$ & 2.951 & 1.641 \\
\hline & $-0.367(\mathrm{Rh})$ & & $9.357(\mathrm{Rh})$ & & \\
\hline & $-0.136(\mathrm{Co})$ & & $9.156(\mathrm{Co})$ & & \\
\hline \multirow[t]{3}{*}{5} & $-0.361(\mathrm{Rh})$ & 0.199 & $9.361(\mathrm{Rh})$ & 2.770 & 1.104 \\
\hline & $-0.417(\mathrm{Rh})$ & & $9.412(\mathrm{Rh})$ & & \\
\hline & $-0.488(\mathrm{Mn})$ & & $7.511(\mathrm{Mn})$ & & \\
\hline \multirow[t]{7}{*}{6} & $-0.333(\mathrm{Rh})$ & 0.005 & $9.325(\mathrm{Rh})$ & 2.951 & 1.291 \\
\hline & $-0.333(\mathrm{Rh})$ & 0.042 & $9.325(\mathrm{Rh})$ & 2.928 & \\
\hline & $-0.406(\mathrm{Rh})$ & 0.043 & $9.389(\mathrm{Rh})$ & 2.927 & \\
\hline & $-0.567(\mathrm{Rh})$ & & $9.592(\mathrm{Rh})$ & & \\
\hline & $-0.499(\mathrm{Rh})$ & & $9.521(\mathrm{Rh})$ & & \\
\hline & $-0.568(\mathrm{Rh})$ & & $9.593(\mathrm{Rh})$ & & \\
\hline & $-0.212(\mathrm{Mn})$ & & $7.242(\mathrm{Mn})$ & & \\
\hline \multirow[t]{6}{*}{10} & -0.375 (Ir) & 0.174 & 9.370 (Ir) & 2.772 & 1.787 \\
\hline & -0.224 (Ir) & & 9.211 (Ir) & & \\
\hline & -0.458 (Ir) & & 9.482 (Ir) & & \\
\hline & -0.683 (Ir) & & 9.698 (Ir) & & \\
\hline & -0.106 (Ir) & & 9.095 (Ir) & & \\
\hline & -0.793 (Ir) & & 9.795 (Ir) & & \\
\hline
\end{tabular}


Table S2. Experimentally observed and calculated ${ }^{11} \mathrm{~B}$ chemical shifts of compounds 2, 3, 5, 6 and 10

\begin{tabular}{lll}
\hline Compound no. & Exp & Calc \\
\hline $\mathbf{2}$ & 121.4 & 116.3 \\
$\mathbf{3}$ & 89.0 & 80.2 \\
$\mathbf{5}$ & 126.6 & 122.3 \\
$\mathbf{6}$ & $96.1,88.8$ & $102.3,93.7$ \\
$\mathbf{1 0}$ & 51.9 & 128.9 \\
\hline
\end{tabular}

\section{Notes and references:}

1. ${ }^{11} \mathrm{~B}\left\{{ }^{1} \mathrm{H}\right\}$ NMR spectra were processed with a backward linear prediction algorithm to eliminate the broad ${ }^{11} \mathrm{~B}$ background signal of the NMR tube by referring to (a) Led, J. J.; Gesmar, H. Application of the linear prediction method to NMR spectroscopy. Chem. Rev. 1991, 91, 1413-1426; (b) Yang, L.; Simionescu, R.; Lough, A.; Yan, H. Some observations relating to the stability of the BODIPY fluorophore under acidic and basic conditions. Dyes Pigm. 2011, 91, 264-267; (c) Weiss, R.; Grimes, R. N. Sources of Line Width in Boron11 Nuclear Magnetic Resonance Spectra. Scalar Relaxation and Boron-Boron Coupling in $\mathrm{B}_{4} \mathrm{H}_{10}$ and $\mathrm{B}_{5} \mathrm{H}_{9}$. J. Am. Chem. Soc. 1978, 100, 1401-1405.

2. Frisch, M. J., et al. Gaussian 09; Gaussian, Inc.: Wallingford, CT, 2010.

3. (a) London, F. Théorie quantique des courants interatomiques dans les combinaisons aromatiques J. Phys. Radium. 1937, 8, 397-409. (b) Ditchfield, R. Self-consistent perturbation theory of diamagnetism Mol. Phys. 1974, 27, 789-807. (c) Wolinski, K.; Hinton, J. F.; Pulay, P. Efficient implementation of the gauge-independent atomic orbital method for NMR chemical shift calculations J. Am. Chem. Soc. 1990, 112, 8251-8260.

4. (a) Becke, A. D. Density-functional exchange-energy approximation with correct asymptotic behavior Phys. Rev. A. 1988, 38, 3098-3100. (b) Lee, C.; Yang, W.; Parr, R. G. Development of the Colle-Salvetti correlation-energy formula into a functional of the electron density Phys. Rev. B. 1988, 37, 785-789. (c) Becke, A. D. Densityfunctional thermochemistry. III. The role of exact exchange J. Chem. Phys. 1993, 98, 5648-5652.

5. Dennington, I. I., Keith, R. T.; Millam, J.; Eppinnett, K.; Hovell, W. L.; Gilliland, R. GaussView, Version 3.09; Semichem Inc.: Shawnee Mission, KS, 2003.

6. Zhurko, G. A. http://www.chemcraftprog.com 